\title{
El retablo mayor de la abadía del Sacro Monte de Granada y su conjunto escultórico de Domingo Cabrera (I746-I748). Datación, documentación y contextualización histórica
}

\section{The Main Altarpiece of the Sacro Monte Abbey of Granada and its Sculpture set by Domingo Cabrera (1746-1748). Dating, Document and Historical Contextualization}

Artículo recibido el I9 de marzo de 20I9; devuelto para revisión el 25 de junio de 20I9; aceptado el 20 de agosto de 20I9; http://dx.doi.org/I0.2220I/iie.I8703062e.2020.116.2716

José María Valverde Tercedor Universidad de Granada. Grupo de investigación Hum 362. josemvalter@gmail.com; http://orcid.org/oooo-0oo2-4950-3552

Líneas de investigación Mecenazgo, patrocinio artístico y Reforma católica.

Publicación más relevante "La Vía Sacra de la abadía del Sacro Monte y el concepto de Granada como Nueva Jerusalén en el marco de la Contrarreforma”, Archivio Italiano per la Storia della Pietà, núm. 28 (2015): I69-2I5.

Resumen En el presente artículo aporto datos documentales inéditos del retablo mayor levantado, a partir de $\mathbf{1 7 4 6}$, en la abadía del Sacro Monte de Granada (España), una institución contrarreformista fundada en I6Io. Entre ellos destaca su autoría, al desconocido imaginero Domingo Cabrera, así como la evolución del proceso de su hechura y colocación, y su contextualización histórica. Ésta se enmarca dentro de los conocidos como "defensorios", los cuales son una serie de textos que tenían como principal función restituir el prestigio del Sacro Monte, puesto en duda a partir de la condena como heréticos de los misteriosos libros plúmbeos que le dieron origen. Asimismo estaban estrechamente ligados a unos nuevos descubrimientos, que acontecieron en la Alcazaba Qadima, del barrio del Albaicín, a mediados del siglo XVIII, impulsados por Luis Francisco de Viana y Bustos, uno de los principales promotores del retablo.

Palabras clave Abadía del Sacro Monte; Granada; retablo mayor; Domingo Cabrera; Gregorio de Espínola; Luis de Viana; Alcazaba Qadima.

Abstract In this article, I provide unpublished documentary data about the main altarpiece constructed as from 1746 in the Sacro Monte Abbey of Gra- 
nada (Spain), the Counter-Reformist institution funded in 16ro. The main findings attribute the authorship to Domingo Cabrera, an unknown sculptor. Other findings worthy of mention are the evolution of the construction and placement of the altarpiece as well as its historical contextualization. The latter is part of a set of texts known as defensorios whose principal function was to restore prestige to Sacro Monte, and which were called into question when their libros plumbeos were considered heretics. Additionally, the defensorios were closely linked to new discoveries that took place in Alcazaba Qadima in Albaicin quarter in the middle of the eighteenth century and that were supported by Luis Francisco de Viana y Bustos, one of the main altarpieces promoters.

Keywords Sacro Monte Abbey; Granada; main altarpiece; Domingo Cabrera; Gregorio de Espínola; Luis de Viana; Alcazaba Qadima. 
DOI: https://doi.org/10.22201/iie.18703062e.2020.116.2716

\author{
JOSÉ MARÍA VALVERDE TERCEDOR \\ UNIVERSIDAD DE GRANADA
}

\title{
El retablo mayor de la abadía del Sacro Monte de Granada
}

\begin{abstract}
y su conjunto escultórico de Domingo Cabrera (I746-I748).
\end{abstract}
Datación, documentación y contextualización histórica

Antecedentes históricos: entre la superchería y la fe

\begin{abstract}
0 ituada al sur de la Península Ibérica, la abadía del Sacro Monte de Granada es una iglesia colegial constituida por un cabildo presidido por la figura de un abad. Fue el proyecto personal del singular arzobispo de Granada y de Sevilla, después: Pedro de Castro (1534-1623). Con fecha fundacional en el año de I6ıo, representa la materialización de una idea nacida a la luz de unos controvertidos sucesos ocurridos a partir de 1595 en el monte donde, según la tradición, tuvo su ubicación un antiguo asentamiento romano conocido como "Ilípula" y que, gracias a ellos, pronto recibió el apelativo de Monte Santo, Santo Monte, Monte Sacro, Sacro Monte o Valparaíso. Estos hechos, muy conocidos y estudiados, consistieron en el descubrimiento de unas láminas sepulcrales las cuales, junto a unas masas y restos humanos, certificaron estar allí los vestigios de los seguidores del apóstol Santiago martirizados en tiempos de Nerón: san Hiscio, los hermanos san Tesifón y san Cecilio, y sus discípulos san Mesitón, san Patricio y san Septentrio, san Maximino y san Lupario, san Turilo, san Panuncio, san Maronio y san Centulio. Todos los restos se asociaron pronto a las reliquias y objetos encontrados en 1588 al derri-
\end{abstract}


bar la Torre Turpiana de la antigua mezquita mayor, ${ }^{\mathrm{I}}$ con lo que se generó un gran revuelo, siendo especialmente llamativo el ocasionado por el hallazgo de san Cecilio (primer obispo de Granada), por haber sido buscado y ansiado desde bastante tiempo atrás. ${ }^{2}$ No obstante, lo que transcendió más, sobrepasando las fronteras nacionales, fue el descubrimiento, junto con ellos, de 2I planchas de plomo que constituían los llamados libros plúmbeos y aspiraban a convertirse en un quinto Evangelio. Estos libros, incisos a buril por sus dos caras, en árabe con modificaciones, causaron gran inquietud puesto que estrechaban lazos entre la religión cristiana y el islam. En cuanto a su simbología se encontraba por un lado "el sigilo de Salomón", que servía de marco a muchos de ellos, y por otro, la inscripción de "A María no tocó el pecado primero", con especial significación en la promoción del culto a la Inmaculada y que a la postre convirtió a Pedro de Castro en un ardiente defensor de la Pureza de María. ${ }^{3}$ Como era de esperar, lo acaecido suscitó una enorme controversia y los debates generados tuvieron pronto una gran repercusión, que superó fronteras, e implicó a reyes y papas. Con motivo de ello, la evaluación de las reliquias no se dilató en el tiempo y se hizo efectiva en un concilio celebrado en Granada en I600. ${ }^{4}$ La determinación de la calificación fue declarar y definir las reliquias de la Torre y las del Sacro Monte como verdaderas. Sin embargo, los libros plúmbeos, mucho más polémicos, fueron trasladados para su análisis, primero a Madrid, después a Roma, y declarados heréticos por Inocencio XI en I682. ${ }^{5}$

I. Este pergamino lo ha estudiado Peter Sjoerd van Koningsveld y Gerard A. Wiegers, "El pergamino de la Torre Turpiana: el documento original y sus primeros intérpretes", en Manuel Barrios Aguilera y Mercedes García-Arenal, eds., Los plomos del Sacromonte. Invención y tesoro (Granada: Universidad de Granada, 2006), II4-I39.

2. Juan Sánchez Ocaña, María Nueva creación. El movimiento Inmaculista y la abadía del Sacro Monte de Granada (Granada: Nuevo Inicio, 20I6), II-I4.

3. Manuel Barrios Aguilera, La invención de los libros plúmbeos. Fraude, historia y mito (Granada: Universidad de Granada, 20II), I07. Sobre la acérrima defensa de Pedro de Castro del inmaculismo y el origen de este fervor en los hallazgos ilipulitanos debe tenerse en cuenta el artículo de José Antonio Peinado Guzmán, "El arzobispo don Pedro de Castro Cabeza de Vaca y Quiñones y la influencia del Sacro Monte en el desarrollo inmaculista en Granada", Historia. Instituciones. Documentos, núm. 42 (2015): 275-295, consultado el 24 de agosto de 2018, en https://bit.ly/2RAEAoh.

4. Del interés que tomó Pedro de Castro en este asunto y el círculo de intelectuales con los que se reunió se trata en José Cárdenas Bunsen, La aparición de los libros plúmbeos y los modos de escribir la historia. De Pedro de Castro al Inca Garcilaso de la Vega (Madrid: Vervuert-Iberoamérica, 2018), 33-98.

5. Diego Nicolás Heredia Barnuevo, Mistico ramillete: vida de don Pedro de Castro, fundador del Sacromonte, ed. Manuel Barrios Aguilera (Granada: Universidad de Granada, 1998), 8I. 
Una de las explicaciones que se le ha dado a los sucesos narrados y a la posterior fundación, en el monte donde acaecieron, de la abadía, es la necesidad de probar el pasado cristiano de la ciudad de la Alhambra y el intento desesperado de consolidar en el Barroco su tratamiento utópico e idealista de "Nueva Jerusalén”, iniciado con la reconquista cristiana en I492; así como consumar la definitiva expulsión morisca de la ciudad. No olvidemos que en este proceso jugó un papel clave Santiago, del que los libros plúmbeos defendían su elección de Granada para celebrar su primera misa en España, por lo que "la promoción de las reliquias del Sacromonte conllevaba la defensa de la causa jacobea" . ${ }^{6}$ Esta utopía se vio beneficiada por la consagración, en I6ıo, de Pedro de Castro como arzobispo de una de las diócesis más ricas del país: Sevilla, lo que hizo que la fama de la institución fuera in crescendo y animó al prelado a emplear en ella todas sus posesiones, tanto propias - heredadas principalmente del mayorazgo de su padre, el gobernador del Perú, Cristóbal Vaca de Castro- como procedentes de las mesas arzobispales de las iglesias granadina y sevillana. Esto se materializó en el encargo de un proyecto muy ambicioso para el Sacro Monte al arquitecto jesuita, Pedro Sánchez. Sin embargo, con la muerte de Pedro de Castro, en I623, el plan se paralizó y la institución se vio sumida en un periodo de crisis, acrecentada por deudas y pleitos, que llegó a su culmen con la citada condena a los libros de plomo. La consecuencia material más evidente de ello fue la merma de su patrimonio artístico y la revisión y censura de sus representaciones plásticas de temática plúmbea.

Empero, en las últimas décadas del siglo xviI se vivió en el Sacro Monte un clima de optimismo, con extensión en la centuria siguiente, gracias principalmente al ejemplo del canónigo sacromontano y arzobispo de Granada: Martín de Ascargorta (1693-1719), gran mecenas y defensor de la causa ilipulitana. En este contexto se enmarca un acontecimiento de gran relevancia: los descubrimientos de la Alcazaba de Qadima, que tuvieron lugar en el Albaicín y fueron motivados por una serie de excavaciones cargadas de superchería. Esto inició en 1754, y se idearon años anteriores, dando como fruto el hallazgo de una columna cilíndrica, de vestigios del concilio de Elvira y de unas planchas de plomo. El culmen fue la aparición de nuevas planchas y láminas que versaban sobre el dogma de la Inmaculada, en I763. Así pues, por su paralelismo con

6. Carlos Santos Fernández, "Pesquisas realizadas en Sevilla para identificar al autor y al impresor de la contradicción a la carta del arzobispo Pedro de Castro en defensa del patronato de Santiago", Historia. Instituciones. Documentos, núm. 35 (2008): 324. 
los descubrimientos de Valparaíso se han considerado un intento desesperado por recuperar, en el siglo XviII, el entusiasmo que en su día suscitaron aquellos hallazgos, tal y como se extrae del Libro de abades y canónigos de la abadía. ${ }^{7}$

El principal protagonista de esta inventiva fue Juan de Flores (I724-I789), ${ }^{8}$ que contó pronto con el fervor popular y el entusiasmo del cabildo del Sacro Monte, especialmente en la persona de Luis de Viana. ${ }^{9}$ Esto ha conducido a Barrios Aguilera a afirmar que lo sucedido desde 1588, "constituye una sola historia". ${ }^{\text {Io }}$ No obstante, la condena a los falsarios se hizo efectiva mediante cédula del 7 de junio de 1774 y la sentencia final se pronunció el 6 de marzo de 1777 , gracias a la intervención en este asunto de personas doctas de distintos lugares del país, como el canónigo Pérez Bayer. ${ }^{\text {II }}$ En este contexto el nuevo retablo se postula como un claro precedente de las excavaciones de la Alcazaba.

7. Archivo de la Abadía del Sacro Monte de Granada (en adelante AAsgr), Fondo Abadía, Libro de abades y canónigos, f. I8Iv. Según se ha dicho, en los mismos confluyen intereses políticos, tanto locales como nacionales. Gloria Mora y Joaquín Álvarez Barrientos, "Las falsificaciones granadinas del siglo XviIr. Nacionalismo y arqueología”, en Barrios Aguilera y García-Arenal, eds., Los plomos del Sacromonte, 52I-53I y José Manuel Roldán Hervás, "Arqueología y fraude en la Granada del siglo XVIII: Juan de Flores y las excavaciones del Albayzín”, Zephyrvs, núm. 85 (1984): 377-396.

8. Natural de Granada, aunque con ascendencia francesa, fue prebendado de la Catedral, "más tarde alcanzó a ser miembro de la Academia de Bellas Artes de Sevilla y examinador sinodal del obispado de Guadix y ministro de la Inquisición”. Véanse Manuel Barrios Aguilera, "Granada en escorzo. Luis Francisco de Viana y la historiografía del Sacromonte", Demófilo, Revista de Cultura Tradicional de Andalucia, núm. 35 (2000): 45-80; Manuel Sotomayor, Don Juan de Flores y Oddoz picaro y mártir. Cultura y picaresca en la Granada de la Ilustración (Granada: Universidad de Granada, 2007), 2I-43; Manuel Barrios Aguilera y Mauricio Pastor Muñoz, Razón del juicio seguido contra los falsificadores de la Alcazaba del Albaicín de Granada (Granada: Universidad de Granada, 20I7), VII-XXIII; y Joaquín Álvarez Barrientos y Gloria Mora Rodríguez, "El final de una tradición: las falsificaciones granadinas del siglo xvıII", Revista de Dialectología y Tradiciones Populares, núm. 40 (1985): 163-190.

9. Barrios Aguilera, "Granada en escorzo", 45-80.

Io. Manuel Barrios Aguilera, "El castigo de la disidencia en las invenciones plúmbeas de Granada. Sacromonte versus Ignacio de las Casas", Al-Qantara, núm. 2 (2003): 477; y Manuel Barrios Aguilera, "El castigo de la disidencia en las invenciones plúmbeas de Granada. Sacromonte versus Ignacio de las Casas”, en Barrios Aguilera y García-Arenal, eds., Los plomos del Sacromonte. Invención y tesoro, 297-233.

II. Como consecuencia fueron condenados Juan de Flores y los clérigos Medina Conde y Velázquez de Echeverría a penas de inhabilitación y reclusión. Manuel Sotomayor, Don Juan de Flores y Oddoz picaro y mártir. Cultura y picaresca en la Granada de la Ilustración, 255-286; Barrios Aguilera, "Granada en escorzo", 50-51; y Barrios Aguilera y Pastor Muñoz, Razón del juicio, VII-XXIII. 
Esto, unido a su conformación iconológica-iconográfica, le hace ser un verdadero adalid de la vocación arqueológica del Sacro Monte.

\section{El retablo mayor antiguo del Sacro Monte (siglo XVII)}

Aunque este estudio está centrado en el retablo mayor nuevo, no puedo dejar en el tintero al que le precedió en la abadía, procedente del periodo fundacional: estaba inspirado genuinamente en los libros plúmbeos y su análisis sirve para confrontarlo con la fábrica dieciochesca. Del mismo se desconoce su cronología, aunque con seguridad, dadas las necesidades de la institución, estuvo listo para la consagración del templo, en i6ıo. En este sentido, teniendo presente la corriente artística del momento, creo que debió ser obra del ensamblador de retablos Miguel Cano, del que se sabe que estuvo muy activo junto a Ambrosio de Vico en los inicios del Sacro Monte, como demuestran sus retablos del Sagrario y la Inmaculada en la iglesia. ${ }^{12}$ En cuanto a los motivos que impulsaron su cambio, junto a la ya analizada renovación ideológica de la institución, se encuentra el elevado nivel de deterioro, como consta gracias a una libranza del I de noviembre i724. La misma registra la entrega de 80 reales de vellón por el mayordomo de hacienda, Bartolomé Rodríguez, al pintor Diego de Hermosilla, ${ }^{\mathrm{I3}}$ por su trabajo de restitución de las lagunas del retablo: "para pagarle su trabajo de pintar las faltas del retablo de este Sacromonte que con

I2. Miguel Cano procede de Almodóvar del Campo (Ciudad Real). Lo encontramos en Granada desde 1587, ciudad en la que trabajó como ensamblador de retablos. Casado con María de Almansa fue padre, entre otros hijos, del célebre Alonso Cano. Antonio Gallego y Burín, El Barroco granadino, ed. Javier Gallego Roca (Granada: Universidad de Granada, 1987), 6I.

13. Desconozco al pintor Diego de Hermosilla. No obstante, llama la atención su apellido, al compartirlo con José de Hermosilla y Sandoval, arquitecto de su misma época muy ligado a la Corte ilustrada. En 1752 lo encontramos como director de arquitectura de la Real Academia de Bellas Artes de San Fernando, donde imprimió las Antigüedades árabes de Granada. Asimismo, en 1766 se le encomendó levantar plantas y alzados de la Alhambra, perfeccionando la obra de Diego Sánchez Sarabia quien, como sabemos, también había trabajado en el Sacro Monte. Véanse Carlos Sambricio, “José de Hermosilla y el ideal historicista de la Ilustración”, Goya, núm. I59 (1980): I40-I5I; Delfín Rodríguez Ruiz, "De la utopía a la Academia. El tratado de arquitectura civil de José de Hermosilla”, Fragmentos, núm. 3 (1989): 58-80; Delfín Rodríguez Ruiz, "Diego Sánchez Sarabia y las antigüedades árabes de España: los orígenes del proyecto”, Espacio, Tiempo y Forma, t. III (1990): 225-257; y María Teresa Cruz Yábar, "José de Hermosilla y el retablo de Irurita en Navarra”, Archivo Español de Arte 73, núm. 290 (2000): 150. 
IOO

esta libranza y sin otro recado se abonarán a vuestra merced en quenta de los siete mill reales que conforme a su obligación ha de dar por este presente mes de la fecha, abiéndose tomado la razón en nuestra contaduría". ${ }^{14} \mathrm{~A}$ propósito de la conformación y morfología del retablo antiguo, a partir de noticias documentales, es posible constatar que fue proyectado como un relicario monumental. A este respecto apunto que la planificación de la iglesia del Sacro Monte como una gran lipsanoteca tuvo su nacimiento en los albores mismos de la institución ilipulitana y vino motivada por el firme deseo de Pedro de Castro de emplazar en la abadía todos los objetos y reliquias aprobados en la calificación de I600, haciendo de este modo frente a las pretensiones del cabildo de la Catedral, que las solicitó para el templo metropolitano. ${ }^{\mathrm{IS}} \mathrm{La}$ llegada de las reliquias a la iglesia colegial se consumó el día 2I de agosto de I6Io. Con motivo de la solemne ceremonia de bendición del nuevo templo, el prelado procedió a disponerlas en los altares colaterales: "inclúyolas en dos urnas de negro jaspe, que engastó en la misma obra del altar mayor, reservando algunas, que repartidas en preciosos relicarios y ricas urnas, pudiesen manifestarse al pueblo los días natalicios de los dichos santos" ${ }^{16}$

Así pues, contamos con una valiosa descripción del retablo mayor antiguo. Expuesta en el cabildo del Sacro Monte el 23 de abril de 1746, sirvió de marco a los debates que se generaron en torno al proyecto iconográfico del nuevo. El retablo era un medio hexágono, compuesto de tres calles, divididas por dos columnas y coronado por otras dos. ${ }^{17}$ En su trama ocupaban un lugar privilegiado las reliquias, entendidas como testimonio del triunfo de los mártires. Junto a ellas, el resto de temas incidían en el culto mariano y cristológico de carácter reformista, como evidenciaban las representaciones de la Asunción de la Virgen (titular del templo del Sacro Monte), muy presente en los santuarios de montańa por su carácter ascendente, y la Santísima Trinidad, perseguida por los protestantes. Asimismo se encontraban otras referencias a la vida de la Virgen en las pinturas de la Anunciación y el Nacimiento de Jesús y a la Pasión,

I4. AASGr, Fondo Abadía, Libranza a Diego de Hermosilla, leg. 54, I de noviembre de 1734.

I5. Finalmente se decidió que las reliquias de la Torre Turpiana permaneciera en la Catedral y las de Valparaíso en el Sacro Monte. Heredia Barnuevo, Mistico ramillete: vida de don Pedro de Castro, fundador del Sacromonte, 95.

I6. Heredia Barnuevo, Mistico ramillete: vida de don Pedro de Castro, fundador del Sacromonte, I4I. 17. AASGr, Actas de cabildo, lib. 8, leg. 261, 23 de abril de 1746, fols. 436r-v. Esta configuración ha sido respetada en el nuevo retablo, pero con la introducción del cambio de estípites por las referidas columnas. 
DOI: https://doi.org/10.22201/iie.18703062e.2020.116.2716

EL RETABLO MAYOR DE LA ABADÍA DEL SACRO MONTE IOI

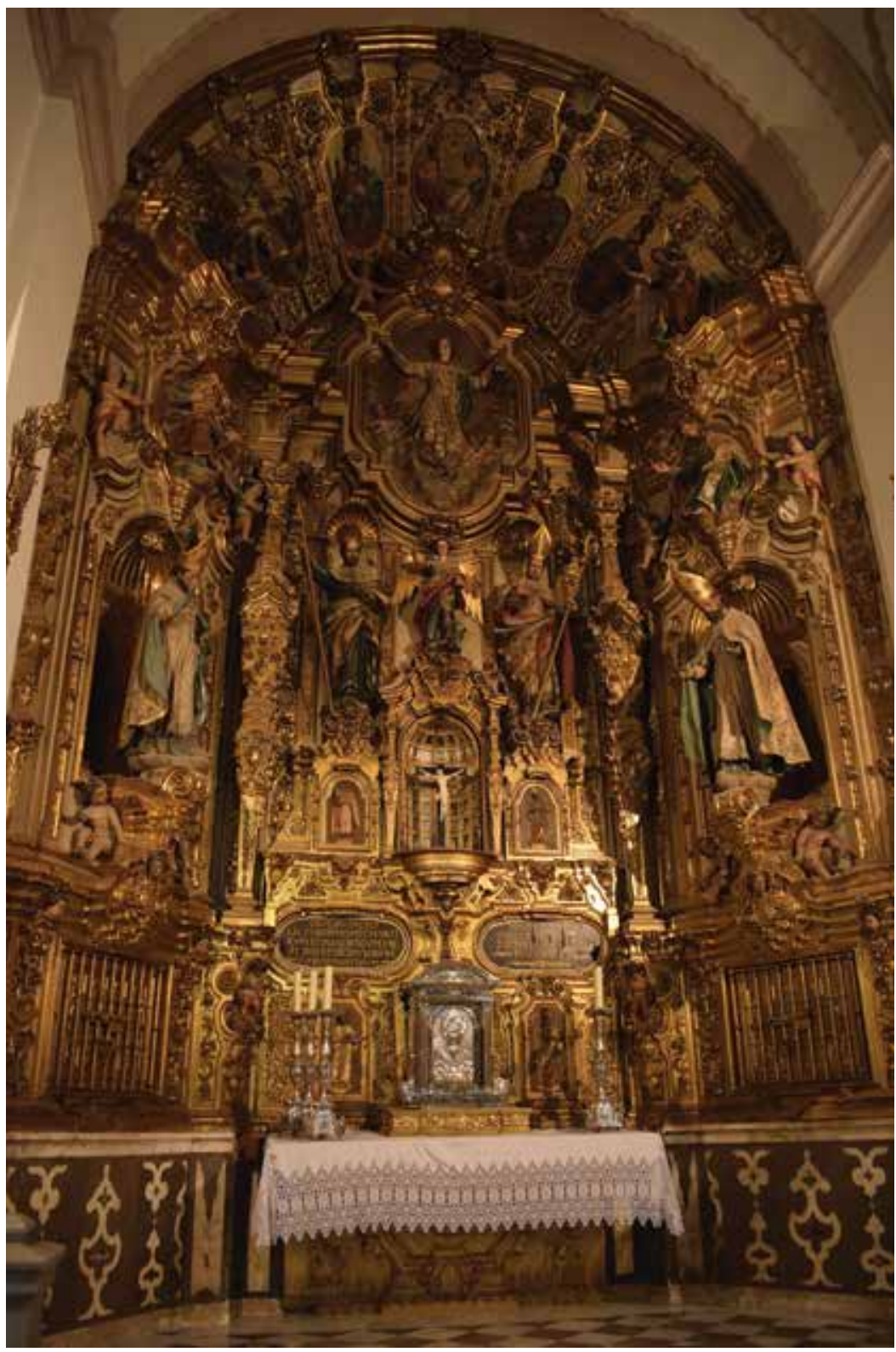

I. Domingo Cabrera y ¿Blas Moreno?, Retablo mayor de la abadía del Sacro Monte, I746-I748, Granada. Foto del autor. 
en el relieve del Ecce Homo del Sagrario, que se sustrajo de la abadía con motivo de la colocación de un nuevo retablo. No obstante, los preparativos para ello siguieron su curso lánguidamente, ya que al principio fue prioritario localizar una estancia para conservarlo antes de su definitivo traslado. A propósito de esto, hubo que esperar al cabildo del 17 de mayo de 1746 para que se concretase el acuerdo de desalojar una de las clases del colegio sacromontano y utilizarla como depósito provisional del retablo antiguo, mientras se le buscaba un nuevo emplazamiento. ${ }^{18}$ Sin embargo, dicho traslado no podría ser consumado hasta que no se despejase el aula por completo: "por no hauer otro sitio, se desocupase la clase, para poner en ella las piezas del retablo y que interin se tuuiese en la cappilla y así se mandó". ${ }^{19}$ La misma suerte corrió el retablo nuevo antes de ser alzado, según quedó expresado en cabildo del I8 de noviembre de 1746. En él se comunicó la noticia dada por el canónigo Viana de que una de las clases del colegio se hallaba ocupada por éste, presentando una serie de inconvenientes ante los cuales el cabildo votó y dictaminó disponerlo en la sala conocida como de los frontales. ${ }^{20}$

Aunque se desconoce la suerte que corrieron las piezas artísticas que formaban el retablo antiguo, se intuye cierto deseo de conservación de las mismas. Esta teoría vino corroborada por el propósito de que, "los dos santos que oi están en el retablo antiguo se lleuen a Daifontes y se separen los tres lienzos de pintura". ${ }^{2 I}$ En este sentido, el debate por el lugar donde debían ser trasladadas las obras del retablo continuó. En relación con ello, en el cabildo del I2 de diciembre de 1746 se hizo pública la manifiesta preocupación por el sitio donde debían destinarse las pinturas del antiguo retablo y ante el precedente envío de las esculturas a Deifontes se siguió idéntica operación: "ytem, se

I8. A nivel edificatorio, la ampliación del colegio fue ideada por el canónigo ilipulitano y obispo de Cádiz, José de Barcia y Zambrana, y consta de dos edificios unidos. El primero, a cargo del arzobispo de Granada, Martín de Ascargorta, fue proyectado en I7II y, el segundo, bajo sustento del arzobispo de Toledo, Diego de Astorga, se concluyó en I724. José de Ramos López, Restablecimiento de los estudios de derecho en el insigne Colegio de teólogos y juristas del Sacro-Monte de Granada: antecedentes históricos de esta famosa escuela y memoria de la solemne inauguración de los expresados estudios en 26 de enero de I896 (Granada: Imprenta de José López Guevara, I897), 8.

I9. AASGr, Actas de cabildo, lib. 8, leg. 26I, I7 de mayo de I746, f. 454r.

20. AASGr, Actas de cabildo, lib. 8, leg. 26I, I8 de noviembre de I746, fols. 488r-v.

2I. AAsGr, Actas de cabildo, lib. 8, leg. 26I, 7 de agosto de 1745, f. 408v. Desconozco a ciencia cierta si dichos santos llegaron a Deifontes. No obstante, puedo afirmar que en la actualidad no se hallan en su iglesia. Deifontes es una localidad de la provincia de Granada (situada en los Montes Orientales) cuyas tierras pertenecieron a la abadía del Sacro Monte. 
determinó que las pinturas del retablo/[494v] antiguo se den para la yglesia de nuestro cortijo de Daifontes". ${ }^{22}$ Por último, señaló que, además de las reliquias y láminas sepulcrales, dicho retablo conservaba los documentos que las validaban en unos contenedores cerrados por una serie de llaves que tan sólo distintas personalidades podían manipular, por lo que acentuaba la oficialidad y ceremoniosidad de cualquier gestión vinculada a ellas, como a continuación se observará.

\section{El retablo mayor nuevo del Sacro Monte (I746-I748)}

La construcción de un nuevo retablo mayor fue el proyecto más importante llevado a cabo en el Sacro Monte a mediados del siglo XvIII, a la altura, en esplendor y significación, de la concesión de privilegios y aprobación de la ampliación de sus estudios en 1752 por el papa Gregorio XIV. ${ }^{23}$ Precedente directo de los descubrimientos de la Alcazaba ya descritos, contribuyó a ponderar y actualizar las reliquias de Valparaíso y supuso una nueva lectura del mensaje de los libros plúmbeos. Las tres personas que lo gestaron y patrocinaron fueron los granadinos Luis Francisco de Viana y Bustos, ${ }^{24}$ Gregorio Eugenio de Espínola ${ }^{25}$

22. AAsGr, Actas de cabildo, lib. 8, leg. 26I, I2 de diciembre de 1746, fols. 494r-v.

23. La primera vez que se habló de todo el protocolo que rodeó a la hechura de una nueva fábrica retablística fue en Zótico Royo Campos, Abades del Sacro-Monte (Granada: Anel, 1964), 129.

24. Principal ideólogo, colegial del Sacro Monte, quien recibió el nombramiento de canónigo en 1716. Cuatro veces rector del colegio que formó las preces de la ampliación de sus estudios. A propósito de su papel en los "defensorios", además del texto que compartió con Laboraria, actuó de comisario del libro de la vida de Pedro de Castro de Heredia Barnuevo. Fue abad durante un corto tiempo (entre 176r y 1762). Por último, a modo de herencia, Luis Francisco de Viana y Bustos quiso dejar tras su muerte un importante legado al Sacro Monte. Prueba de ello es su testamento por medio del cual donó parte de su biblioteca, una de las más ricas que posee la institución. AASGr, Libro de abades y canónigos, fols. I79r-I8Ir; Barrios Aguilera, "Granada en escorzo", 5I-80; Barrios Aguilera, La invención de los libros plúmbeos. Fraude, historia y mito, 325332; y Federico Rodríguez Ratia, El Sacro-Monte. Cuatro siglos de historia educativa en Granada (Granada: Ave María, 2006), 58-60.

25. Se trata de su mecenas. Nacido en Granada. Gregorio Eugenio de Espínola, al que se alude en los documentos como el beneficiado más antiguo de la parroquia de la Virgen de las Angustias, actuó como un gran mecenas, patrono y comitente de obras de arte. AASGr, Fondo Colegio, Libro de registro de entrada de colegiales, leg. 89-I, f. IO7r y AASGr, Fondo Colegio, Libro de registro de entrada de colegiales, leg. 9I-I, f. I27v. Sobre su papel en las iglesias de Granada véase Isaac Palomino Ruiz, "Patrocinio y mecenazgo de Gregorio Eugenio de Espínola sobre templos granadinos", en 
y José Juan de Laboraria. ${ }^{26}$ La primera referencia documental que se tiene del mismo es el compromiso de Laboraria y Espínola, en cabildo del I de julio de 1745 el primero afirmó que: "se me dio comisión en nombre del cabildo para que en todo, y por todo hiciesse lo más conueniente y preciso, arreglándome al fondo del caudal que para esto se ofrecía. De suerte que no le viniesse al cabildo ningún gasto, lo que acepté hacer y cumplir en quanto pudiesse mi cortidad" ${ }^{27}$ A partir de este momento contamos con numerosas citas capitulares en las que se pretendía dar solución a los distintos problemas de diseño del nuevo retablo, surgidos a raíz de la extracción y traslado de las reliquias del antiguo. El primer asunto abordado es el de sus dimensiones. En este sentido, en el cabildo del 20 de julio de 1745 , se planteó derribar la pared sobre la que reposaba el antiguo para aumentar el pavimento alto y, en consecuencia elevar el nuevo, aumentando considerablemente sus proporciones. Esto nos hace partícipes de lo ambicioso del proyecto, con el que parecía querer recuperarse la frustrada idea de Pedro de Castro de dotar al templo de un aspecto monumental, sin embargo, "se// resolvió por la mayor parte, que ni se derribase la pared ni los dichos ochavos, sino es que en el lugar del retablo que hay hoy se coloque el nuevo, solo sí se rebajase una grada del altar mayor para darle esa más anchura". A la conclusión de dicha acta capitular se ideó por primera vez el posible traslado de las reliquias, y se nombraron por comisarios para visitar a las autoridades responsables del mismo a los señores canónigos Martín Vázquez de Figueroa y Miguel de Reina y Trillo: “yttem se determinó que en llegando el caso de quitar el retablo viejo, se determinaría en qué sitio se auian de colocar las reliquias". ${ }^{28}$ Como colofón a dichas discusiones, en el cabildo suce-

María del Amor Rodríguez Miranda y José Antonio Peinado Guzmán, eds., El Barroco. Universo de experiencias (Córdoba: Asociación Hurtado Izquierdo, 20I7), 66-86, consultado el Io de marzo de 20I9, en https://bit.ly/2MeEuFA.

26. Fue el principal comisario durante todo el proceso constructivo. Fue colegial del Sacro Monte y canónigo desde 1744; catedrático de filosofía y teología en la Universidad de Granada. AASGr, Fondo Colegio, Libro de registro de entrada de colegiales, lib. I, leg. 89, f. 204r. AASGr; Fondo Colegio, Libro de registro de entrada de colegiales, lib. 2, leg. 91, f. I5Ov; AASGr, Fondo Abadía, Libro de abades y canónigos, f. 288r. Gran entusiasta de los orígenes del Sacro Monte, lo que le condujo, junto a Viana, a redactar la Historia authéntica, por encargo de Fernando VI. Sin embargo, se ha denunciado que su labor en estas lindes fue "vicaria respecto de Viana [...] y no porque careciera de capacidades intelectuales y de preparación, sino porque debió volcar su dedicación a otras áreas como la Universidad", véase Barrios Aguilera, "Granada en escorzo", 66.

27. AASGr, Fondo Abadía, Actas de cabildo, lib. 8, leg. 26I, I de julio de I745, f. 407r.

28. AAsGr, Fondo Abadía, Actas de cabildo, lib. 9, leg. 26I, 20 de julio de 1745, fols. 407v-408r. 
sivo, del 7 de agosto de 1745 , se tomó la decisión de que su diseño se adaptase al espacio de la iglesia, "como oy está el viejo", con la condición de que el reemplazo solamente se produjese al tiempo de la conclusión del nuevo y de este modo evitar la dispersión de las reliquias. ${ }^{29}$ En cuanto a la iluminación de la fábrica, me consta que estaba conformada por cuatro ángeles lampadarios. A propósito de ello, en el citado cabildo se procedió asimismo a la aprobación de la reubicación de las seis lámparas de plata emplazadas en los arcos del pavimento bajo, colocándose una de ellas en la capilla de Nuestra Señora del Rosario. ${ }^{30}$ De las otras cinco el tesorero debía ordenar fundirlas para la extracción de cuatro homogeneizadas, de gran decoro, para poder utilizarse con regularidad; destinadas a ser sustentadas por cuatro ángeles, de nueva factura, en el retablo, "pudiéndose encender más a menudo, siruiendo así de maior culto y decencia". ${ }^{31}$

A propósito de su diseño. Al igual que ocurrió con el retablo mayor antiguo, el cabildo del 23 de abril de 1746 aporta una valiosa descripción del proyecto del nuevo. El mismo sirvió para acordar su configuración iconográfica y morfología, y en su desarrollo se plantearon una serie de dudas sobre su composición, entre las que se encontraba concretar si había o no de aparecer Santiago o los arcángeles, junto a otros santos. Finalmente, se llegó al acuerdo de que el nuevo retablo tenía que ser fiel, en la mayor medida posible, al anterior, y para ello se nombraron comisarios a los canónigos Luis Francisco de Viana y Bustos, a Antonio López Chinchilla, ${ }^{32}$ y al secretario Miguel de Reina y Trillo. ${ }^{33}$ En este sentido, observamos que su estructura repitió la

29. AAsGr, Fondo Abadía, Actas de cabildo, lib. 8, leg. 26I, 7 de agosto de I745, f. 408v.

30. La capilla de Nuestra Seńora del Rosario de la iglesia del Sacro Monte había sido reedificada en 1744, contando con un nuevo retablo. Esta obra, además del sustento del colegio, contó con el apoyo económico de Gregorio de Espínola. Espínola era miembro de su cofradía y fue colegial ilipulitano. AASGr, Actas de cabildo, lib. 8, leg. 26I, 23 de noviembre de I744, f. 386v.

3I. AAsGr, Fondo Abadía, Actas de cabildo, lib. 8, leg. 26I, 7 de agosto de 1745, f. 408v.

32. Antonio López Chinchilla, nacido en Gualchos, Granada, fue colegial del Sacro Monte y canónigo desde 1742 . Ocupó el cargo de rector del colegio. "Atendiendo a sus méritos y bellas prendas fue electo abad de este Sacro Monte en 1746". Entre las distintas comisiones que ocupó destaca la que compartió con Juan Rodríguez de Aragón en 1763 de las obras de cantería para la ampliación del templo de una a tres naves. AASGr, Libro de abades y canónigos, fols. I5Ov-I5Ir y AASGr, Fondo Abadía, Actas de cabildo, lib. Io, leg. 26I, 22 de agosto de I763, f. 223r.

33. En dicho escrutinio votaron todos los canónigos, a excepción de la abstención de Chinchilla y del secretario. Miguel de Reina y Trillo fue colegial del Sacro Monte y rector del colegio de San Fulgencio de Murcia por deseo del canónigo sacromontano y obispo de aquella diócesis: 
idea de retablo-relicario, "donde se guardan, reciben culto y exponen los restos hallados". 34

Así pues, si analizamos lo proyectado y lo materializado, observaremos que en su hechura se siguió, en líneas generales, el proyecto ideado. A propósito de las divergencias, la principal es la ausencia en la descripción de los relicarios de san Dionisio Areopagita y san Lupario ( $(?), 35$ presentes en el retablo, a ambos lados del manifestador, y la de cuatro ángeles, escoltando por parejas las figuras de san Septentrio y san Maximino. Al mismo tiempo san Maximino y san Lupario (juntos en el relato) aparecen en el retablo separados, el primero bajo la cornisa y el segundo sobre ella, ocupando el lugar que en la descripción se concede a san Centulio. Conviene prestar atención a que, con base en esta idea, san Lupario estaría duplicado en el retablo, hecho que me extraña, por lo que defiendo la teoría de que el santo situado en el relicario es el referido san Centulio.

En el retablo nuevo, respecto al antiguo, se introdujeron algunas singulares variaciones, destinadas a otorgarle una mayor riqueza simbólico-martirial, mediante una mayor concentración escultórica, tanto de bulto redondo como en relieve, prescindiendo en este caso de las pinturas. En él se representan en escultura todos los mártires del Sacro Monte, a diferencia del antiguo en que tan sólo figuraban Santiago y san Patricio en relieve, y san Cecilio y san Tesifón en bulto redondo, a tamaño natural. En cuanto a la temática se denota la ausencia de las representaciones de la Anunciación y el Nacimiento de Jesús que figuraban en el antiguo en pintura junto a la Santísima Trinidad. Respecto a los ángeles y serafines, en el anterior circundaban a la Trinidad en óvalos pintados, figurando en el nuevo en escultura. Por último, se aprecia que, al contrario de lo que sucede en la descripción del retablo antiguo, en la del nuevo se obvian los relicarios, tanto los emplazados con inscripciones sobre el Sagrario, como los situados a ambos lados protegidos por una reja. ${ }^{36}$

Tomás José Ruiz de Montes. Canónigo del Sacro Monte desde I740, "fue mui prudente, callado, asistente a sus obligaciones de la prebenda, delicado theólogo y predicador y de gran juicio en todo". AASGr, Libro de abades y canónigos, fols. 26Iv-262r.

34. Francisco Javier Martínez Medina, Cristianos y musulmanes en la Granada del XVI, una ciudad intercultural. Invenciones de reliquias y libros plúmbeos: el Sacromonte (Granada: Facultad de Teología, 2016), 383. AAsGr, Fondo Abadía, Actas de cabildo, lib. 8, leg. 26I, 23 de abril de I746, fols. $436 \mathrm{v}-437 \mathrm{r}$.

35. Zótico Royo Campos, Abades del Sacro-Monte (Granada: Anel, I964), I3I; y Martínez Medina, Cristianos y musulmanes en la Granada del XVI, 387.

36. Apunto que, al igual que ocurría en el retablo antiguo, en el moderno se encuentran dos grandes cartelas, entre los relicarios principales. En ellas aparecen una serie de inscripciones, en 
DOI: https://doi.org/10.22201/iie.18703062e.2020.116.2716

EL RETABLO MAYOR DE LA ABADÍA DEL SACRO MONTE IO7

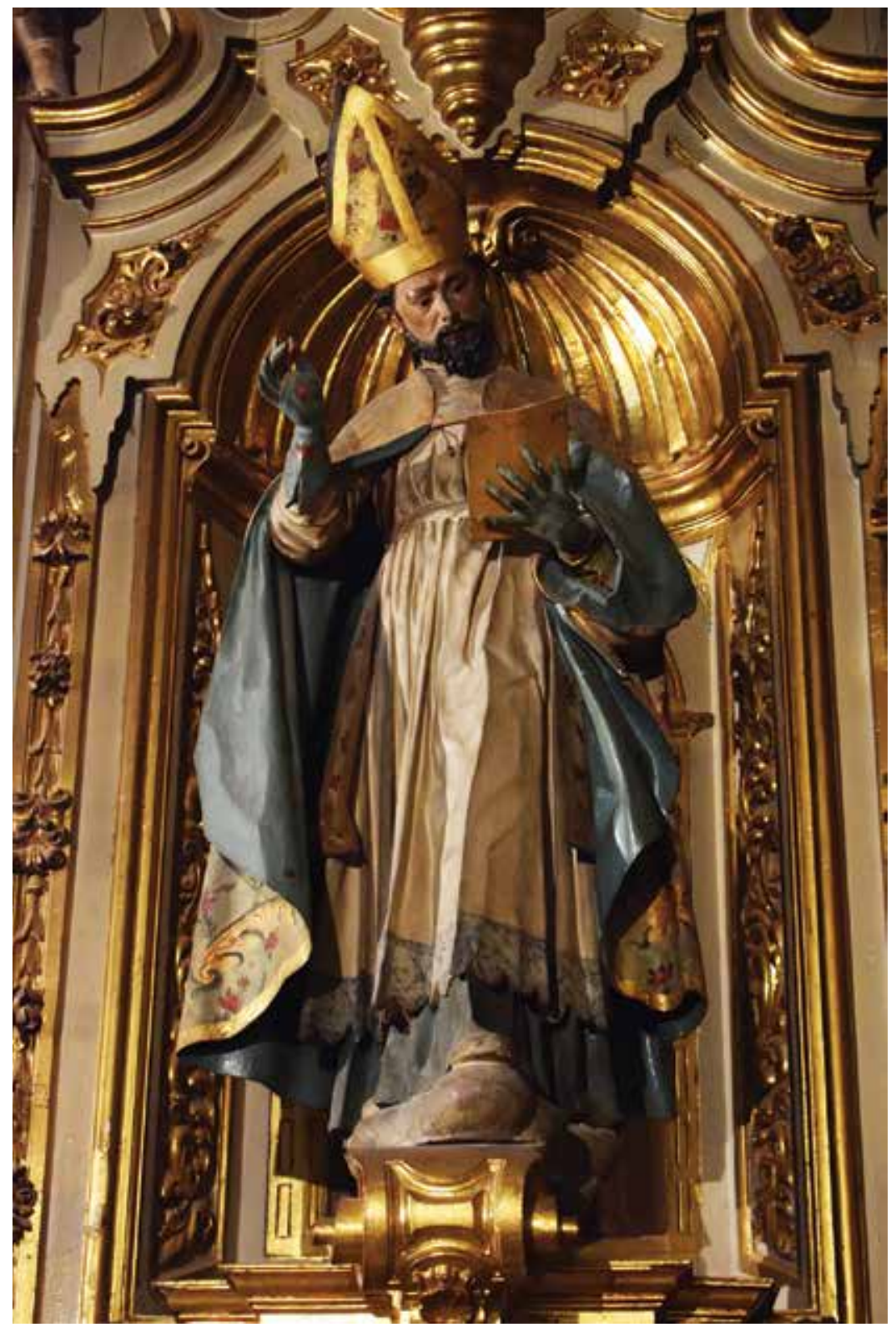

2. Domingo Cabrera, San Cecilio del retablo mayor de la abadia del Sacro Monte, I746-I748, Granada. Foto del autor. 
IO8

Así pues, en cuanto a su simbología, Martínez Medina, en un interesante estudio iconológico, hace un alegato al mismo como una fábrica contrarreformista al servicio del lenguaje de los plúmbeos. ${ }^{37} \mathrm{Al}$ centrarme en el plano estilístico destaco que, como señalé, nos encontramos ante un retablo articulado por un ático conformado por un arco abocinado, dividido en tres calles separadas por dos estípites de gran magnitud. En ellos se aprecia con claridad la evolución experimentada desde los estípites esbeltos y afilados, propios del arte popularizado en la Granada barroca por Francisco Hurtado Izquierdo, hasta los del escultor sevillano Pedro Duque Cornejo, a quien se le considera el precursor de los estípites del Barroco mexicano, conformados por recargados medallones..$^{38} \mathrm{El}$ barroquismo es pronunciado por el oro y la policromía blanca que hace aumentar el relieve de los detalles. ${ }^{39}$ Asimismo, en este retablo llama poderosamente la atención la concentración escultórica, tan sólo comparable en Granada al de San Ildefonso, de cuyo conjunto fue autor José Risueño (su talla y ensamblaje ha sido atribuida a Blas Antonio Moreno).$^{40}$ Esto condujo a Zótico Royo a definirlo como "una página de ricas tallas en la que se concentra toda la historia religiosa de la abadía" ${ }^{41}$ En él, su autor manifiesta importantes alardes técnicos en escultura, representándola en distintos relieves, con lo que consigue fascinantes juegos de profundidades y perspectivas, con su consecuente efecto persuasivo, como demuestran las imágenes de san Miguel y san Rafael, a las que Domingo Cabrera, en una prueba de pericia y de dominio del efectismo barroco, las hace sobresalir de los medallones vacíos en contraste con el resto de tondos, conformados por santos en relieve.

letras doradas sobre fondo negro, que aluden a los mártires. Éstas están acompañadas, en los extremos, por dos relicarios cuadrados, también con leyendas, cerrados por rejas doradas, emplazados en el banco o predela, sobre sotabanco de mármol negro y blanco.

37. Martínez Medina, Cristianos y musulmanes en la Granada del XVI, 385-387.

38. Gallego y Burín, El barroco granadino, 98-99 y 102.

39. De este modo se adelanta al periodo neoclásico en el que se policromará de blanco la madera de los retablos para fingir mármol.

40. Esta característica se ha exaltado, entre otros, por Gallego y Burín, tal y como se manifiesta en José Manuel Pita Andrade, Museo del Sacro Monte (Madrid: Ministerio de Educación, 1964), II-I2. Sobre el retablo de San Ildefonso véanse Domingo Sánchez-Mesa Martín, José Risueño, escultor y pintor granadino (I665-I732) (Granada: Universidad de Granada, I972), 214-224; y Juan Jesús López-Guadalupe Muñoz, "Del Barroco avanzado al neoclasicismo en la retablística granadina del setecientos", Cuadernos de Arte de la Universidad de Granada, núm. 29 (1998): 95. 4I. Royo Campos, Abades del Sacro-Monte, I29-I3I. 
Las imágenes técnicamente presentan un modelado suave, algo blando, propio de buena parte de la escuela granadina de mediados del siglo XviII. Sin embargo, muestran cierta soltura técnica en la resolución de los pliegues de los tejidos y en el llamativo estofado y policromado de los mismos, donde es evidente el influjo oriental ajustado a su centuria. El magno conjunto escultórico del retablo se documenta en este estudio al desconocido imaginero granadino Domingo Cabrera, punto en el que a continuación me detendré. La única obra que conocíamos, hasta el momento, de Domingo Cabrera es el relicario de san Cecilio de la parroquia del barrio del Realejo, también donado por Gregorio Eugenio de Espínola. Se trata de un relicario de plata sobredorada, de I746, del platero José de Bustos. ${ }^{42}$

\section{Traslado de las reliquias del retablo viejo y ceremonia de bendición del nuevo}

Tanto la apertura del retablo viejo, con el consecuente traslado de láminas y reliquias, como la colocación de los objetos sagrados en el nuevo conllevó a una serie de gestiones de marcada oficialidad que implicaron a dos reyes: Felipe V y Fernando VI, y obligaron la intercesión de ilustres personalidades civiles y religiosas.

\section{Apertura del retablo mayor antiguo}

En primer lugar, en el cabildo del I de octubre de 1745 , Laboraria expuso que en una visita que hizo al presidente de la Chancillería le hizo partícipe de la necesidad de escribir al primer monarca borbón, Felipe V, para solicitar su permiso, con el fin de extraer las láminas sepulcrales del retablo antiguo, emplazadas en el lado del evangelio. ${ }^{43}$ Sin embargo, esta operación se pospuso hasta el cabildo del 8 de junio de 1746 cuando se recibieron nuevas noticias del traslado. El mismo se oficializó hasta la sacristía y fue posible gracias a la definiti-

42. Palomino Ruiz, "Patrocinio y mecenazgo de Gregorio Eugenio de Espínola", 7I-75.

43. Según las constituciones este permiso era imprescindible, ya que el Sacro Monte tan sólo podría citar al arzobispo y al cabildo municipal (custodios de dos de las cuatro llaves) una vez que se encontrase en posesión de la real cédula. Dicha información la ratificó el abad, Gaspar Salcedo, quien asintió haber recibido las mismas noticias del presidente. AASGr, Fondo Abadía, lib. 8, leg. 26I, I de octubre de I745, f. 4I5r. 
va llegada de una real cédula, con fecha del 8 de mayo de 1746 en la que el rey autorizaba al presidente de la Chancillería, ${ }^{44}$ el empleo de su llave del depósito de las láminas sepulcrales para la apertura del retablo. Igualmente, consentía que él mismo convocase a los demás depositarios de las llaves: el arzobispo de Granada, el cabildo de la ciudad y el abad, Gaspar Salcedo, para que, con solemnidad, sacasen estos sagrados objetos ante secretarios y escribanos, mandando asimismo que se colocasen en un lugar decente y que de todo ello "se invíe a su magestad testimonios". ${ }^{45}$

Consecutivamente, en cabildo del 4 de julio de 1746 se trató de "determinar sobre presentar a el señor presidente de Granada la real cédula sobre la remoción de las láminas sepulcrales y reliquias de los santos y sobre el quando se ha de poner el nuebo retablo". Para efectuar dicha presentación, recibir y cortejar al presidente de la Chancillería, se nombraron por comisarios a los canónigos Francisco Catalán de Ocón y Martín Vázquez de Figueroa y Peralta. Por otro lado, para hacer la correspondiente legacía al arzobispo y al representante municipal fueron asignados los canónigos Mendoza y Joaquín José de Yparraguirre, "noticiándoles el contenido de dicha real cédula". ${ }^{46}$ Una vez obtenidos todos los permisos, en el cabildo del 28 de julio de 1746 , se dio a conocer el interés de la Orden Hospitalaria de San Juan de Dios por sacar provecho del movimiento de reliquias que se estaban llevando a cabo en el Sacro Monte. A continuación, en dicha sesión capitular, con relación a la real cédula, se declaró su recepción por parte del presidente de la Chancillería. A propósito de ello, el presidente expresó su deseo de asistir a la ceremonia de bendición del retablo. Sin embargo, puso en conocimiento del cabildo su intención de que el acto se celebrase una vez superada la dureza del calor estival y en una ceremonia discreta para economizar gastos. Los capitulares, por su parte, encargaron al canónigo Catalán responderle haciéndole expresión de su agradecimiento e indicándole la intención del Sacro Monte de invitar a todas las autoridades implicadas y de reafirmar su deseo de que esta visita se celebrase durante todo

44. En este periodo el presidente de la Real Chancillería de Granada era Juan Francisco de Isla y Vallado. Pedro Gan Giménez define su mandato como breve y poco interesante ("Pedro Gran Giménez. Los presidentes de la Chancillería de Granada en el siglo XviII", Revista de la Facultad de Geografía e Historia, núm. 4 [1989]: 248).

45. AASGr, Fondo Abadía, Actas de cabildo, lib. 8, leg. 26I, 8 de junio de 1746, fols. 456v-457r.

46. AASGr, Fondo Abadía, Actas de cabildo, lib. 8, leg. 26I, 4 de julio de 1746, f. $459 \mathrm{v}$. 
el día, porque consideraban que un acto de tal envergadura era merecedor de la máxima solemnidad. ${ }^{47}$

Por otro lado, el cabildo del 8 de agosto de 1746 trató acerca de los trámites hechos con el arzobispado y el cabildo municipal para juntar las llaves del relicario y así proceder a la apertura del retablo antiguo. En primer lugar, se aclaró la necesidad de que el canónigo Mendoza diera aviso al arzobispado. En segundo lugar, respecto al concejo, se entregó a una representación del cabildo del Sacro Monte en las salas capitulares conformada por un caballero veinticuatro y un jurado, quien agradeció y aceptó su participación, comprometiéndose a hacerse presente por medio de un caballero elegido por sorteo. A continuación, de nuevo se presentó un debate sobre el espacio que debían ocupar las láminas y reliquias durante el tiempo en que durase la hechura y colocación de un nuevo retablo, en este caso ocasionado por la diatriba de si éstas podrían juntarse provisionalmente o si, al contrario, debían continuar en alhacenas separadas..$^{4}$ A propósito de esto, se expuso el título segundo de las constituciones, el cual disponía que las reliquias debían conservarse bajo dos llaves: una en posesión del abad y la otra del canónigo tesorero, y las láminas sepulcrales tenían que ubicarse en un relicario al lado del evangelio, bajo cuatro llaves: una de ellas bajo custodia del presidente de la Chancillería, en representación del rey, otra del arzobispo, una más en manos del abad del Sacro Monte y la última en posesión del municipio de Granada. Por tanto, existía cierto temor a que si se unificaban reliquias y láminas alguno de los representantes civiles o eclesiásticos tuviese acceso a la llave de ellas. Ante esto, el cabildo del Sacro Monte tomó la deliberación de que no había ningún inconveniente en que láminas y reliquias compartiesen depósito bajo las cuatro llaves si bien estarían sujetas a una serie de reservas: en primer lugar, los autos que se elaborasen se atendrían a la primera constitución del título segundo. Y, en segundo lugar, una vez finalizadas las obras, dichas reliquias y láminas deberían quedar en su emplazamiento primigenio, sin ninguna alteración, llegándose al definitivo acuerdo de que se ubicasen en un mismo depósito. Finalmente, ante las recomendaciones del abad, Gaspar Salcedo, se tomó la decisión de dejar fuera un relicario para poder acudir a él en caso de necesidad o devoción. ${ }^{49}$ Sin embargo las buenas intenciones duraron poco tiempo y en cabildo del i6 de agos-

47. AAsGr, Fondo Abadía, Actas de cabildo, lib. 8, leg. 26I, 28 de julio de 1746, fols. 462v-464r. 48. Así sucedía con el retablo antiguo.

49. AASGr, Fondo Abadía, Actas de cabildo, lib. 8, leg. 26I, 8 de agosto de I746, fols. 465r-468r. 
to de 1746 , el abad manifestó su disconformidad ante lo expresado y decretó nula la determinación capitular alegando que no guardaba las constituciones, las cuales daban privilegio al Sacro Monte. ${ }^{50}$

Estos desencuentros hicieron que el acuerdo se dilatase más de lo deseado y es por ello que tendremos que esperar al cabildo del ro de octubre de 1746, para que se concretase la ceremonia de apertura del retablo antiguo. En él una vez más se discutió acerca del modo más adecuado de facilitar el traslado de las reliquias. Por decreto de la real cédula de Fernando VI, dirigió el timón en estas operaciones la Real Chancillería. Para llevar a cabo la maniobra, según informa Gaspar Salcedo, el presidente acordó la asistencia con sus respectivas llaves, del arzobispo granadino, Felipe de los Tueros y Huerta, ${ }^{\text {sI }}$ y del gobierno municipal, el jueves día I3. El cabildo sacromontano, por su parte, nombró como comisarios para recibir y asistir al presidente de la Chancillería, a los canónigos Catalán, Viana y Heredia. Los dos capitulares más antiguos, acompañados de dos colegiales y representantes del colegio, deberían recibir al presidente en las escaleras de la "placeta de los coches" y acompañarlo hasta la capilla de la Concepción de las Cuevas (de Santiago), lugar en el que sería recibido por el abad, Gaspar Salcedo, junto a otros dos canónigos y otros dos capellanes..$^{52}$

Ello respecto a los asuntos protocolarios concernientes al acto religioso de apertura del retablo. En cuanto a la organización de la iglesia, se acordó que el presidente de la Chancillería se sentase en la capilla de Nuestra Señora del Rosario y junto a él se situase el representante del arzobispo. En la nave central se ubicarían los miembros del poder municipal con sus secretarios. Por último, se le dio al abad Gaspar Salcedo la orden de comunicarle al dicho presidente que planificase su llegada entre las 8 y las 9 de la mańana del jueves, y de este modo, poder preparar la iglesia con más esmero. ${ }^{33}$ Debido a que esta ceremonia conllevaba un cambio

50. AASGr, Fondo Abadía, Actas de cabildo, lib. 8, leg. 26I, I6 de agosto de 1746, fols. 470r-v.

5I. Felipe de los Tueros y Huerta, de origen vizcaíno, fue arzobispo de Granada entre 1734 y I75I. https://bit.ly/2TGgfpX (consultado el Is de febrero de 2019).

52. Esto se convierte en una prueba de la consumación del Carril de los coches como nuevo espacio ritual de la alta sociedad. El Carril de los coches fue un camino promovido en 1738 por Diego Nicolás de Heredia Barnuevo para facilitar el acceso de la nobleza granadina a la abadía y contó con el apoyo y sustento del cabildo municipal, especialmente representado por las personas de Juan de la Cueva y Pascasio de Bańos. El primero fue su gran mecenas y el segundo actuó como su comisario y costeó el monumento a la Inmaculada, que significó la culminación del itinerario. AASGr, Fondo Abadía, Libro de abades y canónigos, fols. 203r-208r.

53. Muy activo en todas las gestiones ligadas al nuevo retablo, lo encontramos como colegial del Sacro Monte y como canónigo desde 1739. Fue abad desde el 4 de abril de 1743. El Libro de 
en el calendario del templo, y que en este momento eran muchas las celebraciones en el Sacro Monte, se llegó al acuerdo de que "para que a esta hora esté desembarazada la yglesia se anticipe la misa de tercia y se celebre//[48Ir] después de horas menores". ${ }^{54} \mathrm{~A}$ la liturgia se le quiso dotar de la más amplia solemnidad. Por ello, se concretó que el abad, Gaspar Salcedo, vistiese de capa pluvial, ataviándose con sobrepellices los canónigos comisarios y el canónigo Reina, como secretario del cabildo, al igual que los capellanes "de casa y collegio". Asimismo, se concertó la escolta de seis colegiales, con sendas hachas alumbradas. Por otro lado, el sacristán debía disponer al pie del altar mayor el aparador con la plata de la iglesia y una mesa con telas lujosas: "sobremesa rica y mantel correspondiente para poner sobre las láminas sepulchrales y sagradas reliquias". 5 Éstas se irían sacando simultáneamente, para dar fe de la autenticidad de cada una de ellas y que una vez adoradas por los asistentes, fuesen trasladadas a la sacristía, a un espacio pertinente, habilitado para ello. La extracción de las láminas sepulcrales sería dirigida por el abad, quien tenía el cometido de mostrar, a cada uno de los claveros, la cerradura correspondiente a cada llave de la urna de ellas. Como medida de prevención el cabildo contaría con la figura de un maestro cerrajero encargado de abrir aquellos candados de los que no se tuviese llave. Una vez finalizado dicho traslado, con relación a las reliquias, se procedería a realizar lo mismo con los relicarios, para ello el canónigo tesorero se vestiría con capa pluvial y el abad, acompañado de "su señoría", ${ }^{56}$ los abriría con las dos llaves que le correspondían para proceder a exponerlos a la "veneración y adoración" de los fieles antes de ser procesionalmente trasladadas al depósito destinado para ellas en la sacristía, al igual que se había efectuado antes con las láminas. ${ }^{57}$

Como colofón a la celebración litúrgica señalada se acordó la preparación de un convite por la tarde. Éste era una versión austera y reducida de las lujosas celebraciones barrocas del siglo XviII. ${ }^{58}$ Para ello se concretó también conce-

abades y canónigos resalta que en su periodo al frente de la abadía se les concedió licencia a los hermanos Castañeda para labrar sus viviendas, así como potestad a los canónigos José Montero y Julián de Villavicencio para construir en el intermedio de las dos torres. Estas edificaciones, unidas a la casa de Jacinto Ruiz Velarde, de la que fue nombrado comisario en I742, constituyeron la ampliación más importante del conjunto residencial de la abadía desde el periodo fundacional. AASGr, Fondo Abadía, Libro de abades y canónigos, fols. 285v-287v.

54. AAsGr, Fondo Abadía, Actas de cabildo, lib. 8, leg. 26I, Io de octubre de 1746, fols. 480v-48Ir. 55. AASGr, Fondo Abadía, Actas de cabildo, lib. 8, leg. 26I, Io de octubre de I746, f. 48Ir.

56. Debe referirse al representante del arzobispo de Granada.

57. AAsGr, Fondo Abadía, Actas de cabildo, lib. 8, leg. 26I, Io de octubre de 1746, fols. 480r-v. 58. El paradigma de todos ellos lo representa la dedicación de la Basílica de San Juan de Dios 
der al proveedor, el canónigo Martín Vázquez de Figueroa, lo necesario para llevarla a buen término, corriendo todo ello a cargo de la junta de asistentes. Dicha comida se llevaría a cabo en las recién estrenadas casas de Jacinto Ruiz Velarde ${ }^{59}$ y los encargados de solicitarla fueron los canónigos Viana y Vázquez. Organizada de forma jerárquica, en la sala principal, "los señores ilustrísimo presidente y demás claveros" se encontrarían acompañados por el abad y los canónigos comisarios. Iría exornada por un rico aparador decentemente guarnecido. En otra se dispondría una mesa para familias junto a dos capellanes sacromontanos. Por su parte, en una sala baja se ubicaría una mesa para los criados. Para que todo discurriese de forma correcta se nombraron por comisarios a los canónigos Aranda y Laboraria. Ellos deberían, al mismo tiempo, dar hospedaje y cuidado en sus cuartos a los oidores y dirigir la asistencia de los inquisidores en el caso de que éstos concurriesen. Gregorio de Espínola fue invitado a este evento como bienhechor del retablo, "a cuya devoción y espensas se ha costeado". No obstante, a causa de su elevada edad, acordaron darle un trato especial, siendo recibido en el cuarto del canónigo Laboraria. Por entender el cabildo que éste pondría reparos en concurrir con las autoridades, por lo farragoso que dicho compromiso podría antojársele, se le permitió invitar a los compañeros beneficiados que gustase. Los canónigos nombrados para convidarlo en nombre del cabildo fueron Viana y Laboraria. ${ }^{60}$

de Granada el 27 de octubre de 1757, cuyo principal promotor, como comisario del ayuntamiento, fue Pedro Pascasio de Baños, quien prestó su casa para celebrar importantes festejos. Alonso Parra y Cote, Fiestas de San Juan de Dios de Granada, ed. facs. (Granada: Caballeros del Santo Sepulcro de San Juan de Dios, 2008), 298; Gallego y Burín, El barroco granadino, I20-I2I y I67-I68; y Ana María Gómez Román, "Moral aristocrática, filantropía y promoción de la figura de Pedro Pascasio de Baños", Cuadernos de Arte de la Universidad de Granada, núm. 36 (2005): I4I-I42.

59. La casa de Jacinto Velarde constituye la materialización de una de las obras pías más significativas de la abadía del Sacro Monte. Velarde es un caballero de Granada que decidió fijar su residencia en la institución ilipulitana como agradecimiento al buen trato dispensado por la institución tanto a él como a su hijo, el colegial sacromontano, Vicente. El edificio, convertido, tras su muerte, en residencia de capellanes y canónigos, significó la ampliación más importante a la fábrica del Sacro Monte en su vertiente occidental, desde la fundación de la abadía y data de I743. AASGr, Fondo Abadía, leg. 86, "Traslado de la aceptación y aprobación de la obra pía que instituyó y fundó el señor doctor Jacinto Ruiz Velarde”, I6 de abril de 1743.

60. AASGr, Fondo Abadía, Actas de cabildo, lib. 8, leg. 26I, io de octubre de 1746, fols. 480r-v. 


\section{Colocación y bendición del retablo mayor nuevo}

Una vez superado el traslado de las láminas sepulcrales y reliquias del antiguo retablo, en el cabildo del 27 de octubre de I746, "propuso el señor abbad cómo se estaba ia empezando a poner en el altar maior de nuestra yglesia el nuebo retablo que a su deboción costea el maestro don Gregorio de Espínola". ${ }^{61}$ Animado por ello, Gaspar Salcedo creyó conveniente realizar, antes de que se produjese el definitivo emplazamiento, tareas de clasificación e identificación de las reliquias que se hallaban en cajones de piedras, embebidos en la pared en el altar mayor. Dada la importancia de las operaciones, el cabildo acordó llevarlas a efecto de forma privada y sin mayor oficialidad. Concurrieron, además del abad Salcedo, todos los miembros del cabildo acompañados de Gregorio Eugenio de Espínola, junto a otro beneficiado. ${ }^{62}$ El acto de apertura de los cajones tuvo gran solemnidad y contó con la presencia de una serie de colegiales portando hachas encendidas. Tras esto fueron subiendo todos los presentes a adorar las reliquias, experimentando el aroma de una singular fragancia. ${ }^{63}$ Las tareas de colocación del nuevo retablo no tardaron en exceso, como se deduce, ya que, aproximadamente mes y medio después de su inicio, con motivo de la proximidad de las fiestas de Navidad, la nueva fábrica se encontraba ya en proceso de finalización. Ante ello se tomó la determinación de que se realizasen dichas intervenciones de colocación, abonando el dinero necesario el comisario de dicha obra, Laboraria, junto al secretario Miguel de Reina. ${ }^{64}$

En el cabildo del I9 de mayo de 1747 se dejó constancia, por el abad Gaspar Salcedo, de haberse reconocido los autos del depósito de las láminas sepulcrales y la cédula real. Asimismo, se hizo saber que el rey Fernando VI demostró su deseo de recibir testimonio de la operación. Para pedir la cédula se decidió enviar al monarca una carta, de mano de los comisarios del retablo, y escribir otra al secretario de cámara, donde se incluyesen los autos hechos cuando se depo-

6I. AASGr, Fondo Abadía, Actas de cabildo, lib. 8, leg. 26I, 27 de octubre de 1746, f. 485r.

62. Como vemos Gregorio de Espínola tuvo una presencia privilegiada en todos los actos vinculados de forma, más o menos directa con el nuevo retablo, incluso en aquellos de carácter interno y por ende menos oficial.

63. Ésta nos recuerda a la que se produjo en el descubrimiento de las reliquias, a partir de 1595 .

64. Con ello se pretendía dar respuesta al deseo de que dicho altar presidiese los oficios religiosos natalicios. No obstante, para poder llevarlo a efecto, era necesario dorar, como mínimo, el Sagrario de dicho retablo y disponer en él unas palmatorias de bronce. AAsGr, Fondo Abadía, Actas de cabildo, lib. 8, leg. 26I, I2 de diciembre de 1746, f. 495r. 
sitaron las láminas. Ambas irían firmadas en nombre del cabildo por el presidente y el canónigo, Pastor, por ser el más antiguo. De este modo pararían en manos de Gaspar Salcedo quien sería el encargado de dárselas al presidente de la Chancillería, para agilizar las gestiones, para que él las dirigiese con su recomendación al secretario de cámara, agradeciéndole por su buena voluntad. Al instar igualmente a dicho abad a citar a cabildo con prontitud. ${ }^{65}$

Sin embargo, para dar lectura a la real cédula de Fernando VI, tendremos que esperar al cabildo del 4 de junio de 1747 . En ella se ordenaba al presidente de la Chancillería que juntase las llaves del depósito de láminas de plomo y pidiese que estos objetos fuesen devueltos al relicario del retablo nuevo, con la solemnidad que se hizo al extraerlos, ubicándolos en su emplazamiento original, del lado del evangelio. Tras recitar dicha cédula, el cabildo llegó al acuerdo de nombrar a los canónigos Catalán y Vázquez comisarios y les pidió que comunicasen al presidente de la Chancillería el ofrecimiento del abad Gaspar Salcedo de invitar al traslado a las personas que él creyese más convenientes. En cuanto al trato con otras instituciones, en lo que concierne al Cabildo municipal y al Arzobispado, fueron nombrados el canónigo Heredia y el secretario Miguel de Reina, para informarles, junto a dos de sus capellanes, acerca de la cédula. Asimismo, se acordó que el acto propio de la entrega de las reliquias y el de la realización de los autos judiciales a ellas asociados fueran en días distintos debido al calor acuciante.

En este aspecto se pactó comunicar al presidente de la Chancillería que con motivo de la devolución, fijada el día de la Inmaculada, se celebrase una misa rezada en el altar mayor con el canto del Te Deum laudamus acompañado por instrumentos musicales, con la organización del canónigo Antonio Sánchez. ${ }^{66}$ En ella, el sermón sería predicado por el canónigo catalán. Igualmente se aprobó la propuesta del abad, Gaspar Salcedo, de que la referida homilía se dedicara al rey y que se imprimiera tras haber sido sometida a la revisión y censura, si procediera, de dos calificadores del Santo Tribunal de la Inquisición. Asimismo, con motivo de esta causa se estamparían las dos cédulas reales del depósito y devolución de las láminas. La forma de sufragar estos gastos debía ser con el caudal procedente de los I, 500 reales consignados para el aniversario anual

65. AAsGr, Fondo Abadía, Actas de cabildo, lib. 8, leg. 26I, i9 de mayo de 1747, fols. 53Ir-532r. 66. Antonio Sánchez Fernández fue colegial del Sacro Monte y canónigo desde I729. Rector del colegio, se trata asimismo de uno de los tesoreros más célebres de la abadía. Desde este oficio se hizo cargo de que "se hiciese la costosa y primorosa obra de la nueva caxonería, que está acabada en diciembre de I760". AASGr, Fondo Abadía, Libro de abades y canónigos, fols. 420r-v. 
de la Inmaculada, tras la votación de los capitulares, quienes cedieron su parte voluntariamente. ${ }^{67}$

Así pues, al igual que ocurrió el día del traslado de las reliquias y láminas del antiguo retablo, también en el depósito de las mismas al nuevo, se planeó la celebración de un banquete. En este caso la comida sería organizada por los miembros de la junta de asistentes, nombrándose al canónigo Antonio Sánchez para que ayudase al proveedor en todo lo relativo a la disposición de la "comida, messa, agasajo y cortejo". El protocolo a seguir, tanto en la misa como en el recibimiento del presidente de la Chancillería, coincidirá también con el organizado en la ceremonia de apertura del retablo, citando para ello la asistencia de comisarios, canónigos, capellanes y colegiales. ${ }^{68}$ En el cabildo del i8 de junio de 1747 el canónigo Heredia dio respuesta de su legacía al Ayuntamiento granadino y al Arzobispado sobre el contenido de la real cédula que tenía ya en posesión, para la devolución. Finalmente se anunció que, según había afirmado Gaspar Salcedo, el presidente de la Chancillería había reservado para dicha ceremonia de devolución de las láminas sepulcrales y reliquias el día de santa Ana. En efecto, el definitivo traslado de las láminas sepulcrales a su depósito en el altar mayor fue en la mañana del 26 de julio de $1747 \cdot{ }^{69}$ Contó con la presencia del presidente de la Chancillería de Granada y junto a él el resto de portadores de llaves de los depósitos. Todos fueron recibidos por los comisarios del cabildo del Sacro Monte y se reunieron en la sacristía, donde de manera simultánea fueron abriendo la alhacena o relicario. En primer lugar la abrió el presidente de la Chancillería, en nombre del rey, acompañado del escribano de cámara y secretario del acuerdo, Pedro Rodríguez de la Cueva. A éste le siguieron las autoridades religiosas y civiles de la ciudad: el canónigo de la Catedral de Granada y juez eclesiástico de rentas reales, Salvador de Espinosa, que acudió en nombre del arzobispo, ${ }^{70}$ junto a José de Castro, notario mayor de rentas del Arzobispado, acompañado del caballero veinticuatro, Agustín García, del caballero veinticuatro decano, Pedro Jauregüi, y del decano de la ciudad, José Matute Jurado. Asimismo asistió el secretario del Cabildo municipal, Francisco Noguerol.

67. Respecto a los ausentes quedaría a libre elección de cada uno de ellos el ceder o no dicha cantidad.

68. AASGr, Fondo Abadía, Actas de cabildo, lib. 8, leg. 26I, 4 de junio de 1747, fols. 54IV-544r.

69. AASGr, Fondo Abadía, Actas de cabildo, lib. 8, leg. 26I, I8 de junio de I747, fols. 55Iv-552v.

70. El arzobispo de Granada había excusado su ausencia en el cabildo del i8 de junio. 
Según el orden establecido por el protocolo, el abad del Sacro Monte, Gaspar Salcedo, procedió a la apertura del depósito o alhacena, ante el secretario Miguel de Reina. Tras extraer las cuatro láminas sepulcrales, dispuestas en tablas de cedro, una caja pequeña de plomo betunada, otra de madera con algunos alambres, y dos piedras, las colocaron sobre el bufete de la sacristía. ${ }^{71} \mathrm{~A}$ continuación, fueron reconocidas por los comisarios, los cuales iban acompañados de sus respectivos secretarios. Tras ello fueron colocados en unas fuentes de plata por los capellanes sacromontanos y los condujeron al altar mayor. En cuanto al orden en el templo, el presidente de la Chancillería se emplazaría en una silla con sitial bajo junto al arco de la capilla del Rosario, el comisario del arzobispo en una silla sin sitial en el arco de la capilla de Ceremonias y los representantes del Municipio en cinco escaños de damasco emplazados en el cuerpo de la iglesia. ${ }^{72}$

$\mathrm{Al}$ aprovechar este traslado, los objetos sagrados fueron expuestos al pueblo durante un breve tiempo, tras el que se pasó a su definitivo depósito en ara dorada en el retablo "en la misma forma u sitio que estaba en el antiguo retablo y cubiertas con un cendal carmesî". En este momento, según testimoniaron los secretarios $y$, al igual que en la ceremonia de apertura del antiguo retablo, se subieron ordenadamente las autoridades acompañadas de los canónigos comisarios y cerraron los relicarios con una llave dorada, con el siguiente orden y cometido: en primer lugar, el presidente de la Chancillería cerró la puerta interior del depósito de madera sobredorada, con una cartela en la que se lee: Gloriam, regni tui dicent. A continuación, el comisario del arzobispo cerró el candado superior de la reja de hierro que asegura exteriormente el depósito. El caballero veinticuatro cerró el candado interior de dicha reja y el abad cerró de golpe la cerradura que hay en medio de la reja. Una vez concluido el traslado de las láminas sepulcrales se dio paso al de las reliquias. En este caso, dicha ceremonia revistió un carácter menos oficial, pero mucho más emotiva, y estuvo

7I. Se refiere a la "Mesa de cálices" o "Mesa de Commesso" de la sacristía de la abadía. Es, sin lugar a dudas, una de las piezas más singulares de la institución ilipulitana y fue comprada por el cabildo del Sacro Monte a Sevilla, siendo Pedro de Castro arzobispo de la ciudad hispalense, según el cabildo del 2 de noviembre de I62I. AAsGr, Fondo Abadía, Actas de cabildo, lib. I, leg. 258, 2 de noviembre de I62I, f. 309r. Este cabildo se publicó en Isaac Palomino Ruiz y José Antonio y Peinado Guzmán, "Piezas inéditas del patrimonio de la abadía del Sacro Monte en Granada", 55 , en https://bit.ly/2k6qpi3. Por su parte la mesa ha sido estudiada por María Paz Aguiló Alonso, "Para un corpus de las piedras duras en España. Algunas precisiones", Archivo Español de Arte, núm. 299 (2002): 255-267, consultado el Io de febrero, 2015.

72. AASGr, Fondo Abadía, Actas de cabildo, lib. 8, leg. 26I, 26 de julio de 1747, fols. 554r-547r. 
protagonizada por el cabildo del Sacro Monte personificado en las figuras del abad, Gaspar Salcedo, y el tesorero y secretario, Miguel de Reina y Trillo, quienes, vestidos de estolas y capas pluviales carmesíes, fueron escoltados por todos los prebendados y colegiales sacromontanos, los cuales portaron luces. En dicho traslado se cantó el himno Te Deum laudamus, e interpretó el coro de la iglesia con un concierto de música. Concluida la solemne procesión en el altar mayor, se procedió a exponer en adoración las citadas reliquias. Los asistentes subieron de dos en dos y tras finalizar dicho acto se ubicaron en el lugar a ellas destinado, en correspondencia con el que ocuparon en el antiguo retablo. A ambos lados del manifestador, en pequeños relicarios se dispusieron dos urnas de madera, con cristales y columnillas, las cuales contienen masas y cenizas de santos. Consecutivamente, en las dos que escoltan al Sagrario, se ubicaron dos relicarios ochavados de metal dorado fundido a fuego. El relicario cerrado con reja, del lado de la epístola, fue contenedor de una urna de ébano y cristales engarzada en plata, el lignum crucis, ${ }^{73}$ la canilla de san Mesitón y los dos relicarios con los cubos de las cenizas, con forma de ángeles. Hecho dicho depósito se cerraron los contenedores. La finalización de dicha ceremonia estuvo protagonizada por la oración de acción de gracias y la de los mártires, de parte del abad Salcedo. El testimonio puntualiza, al final del mismo, la asistencia como testigos de representantes de la Real Chancillería, inquisidores y varias dignidades de la Iglesia y canónigos procedentes de otros cabildos, acompañados de diversos religiosos tanto del clero regular como del secular, arropados por una numerosa representación del pueblo. ${ }^{74} \mathrm{Al}$ alegar el calor que concurría el día de la colocación de las reliquias y láminas sepulcrales, por ser entrado el verano, la ceremonia solemne de devolución de dichos sagrados objetos quedó aplazada a la Inmaculada Concepción, como se declara en el cabildo del 22 de octubre de 1747. Sin embargo, el encontrarse ocupado el canónigo Catalán en dicha fecha y no poder dar el sermón, unido a las faltas de fondos necesarios para darle mayor esplendor, hizo que se suspendiera. Igualmente se decretó que el presidente de cabildo encargara el sermón ordinario de la Inmaculada al canónigo que creyese más adecuado para ello. ${ }^{75}$

73. El lignum crucis acompañó a Pedro de Castro durante su vida y fue donado por él, por medio de su testamento. Aasgr, Fondo don Pedro de Castro, "Testamento de Pedro de Castro (copia)", leg. I, parte I, fols. 843r-v.

74. AASGr, Fondo Abadía, Actas de cabildo, lib. 8, leg. 26I, 26 de julio de 1747, fols. 554r-547r. 75. AAsGr, Fondo Abadía, Actas de cabildo, lib. 8, leg. 26I, 22 de octubre de 1747, fols. 572v-573v. 
DOI: https://doi.org/10.22201/iie.18703062e.2020.116.2716

$\mathrm{I} 2 \mathrm{O}$

JOSÉ MARÍA VALVERDE TERCEDOR

\section{Pago del retablo mayor nuevo y autoría del conjunto escultórico}

Los pagos de Gregorio de Espínola para esta empresa se fueron sucediendo desde el año de 1745, concluyendo con su testamento en 1750. Los mismos nos ayudan a tomar conciencia del trabajo de distintos artesanos en esta obra. Así, por ejemplo, se ha reflejado la entrega de Gregorio Eugenio de Espínola de II5 reales a Bernabé de Haro, ${ }^{76}$ por la herrería, y de 16,395 reales de vellón en concepto de dorado y policromado, dividiéndose 7,800 reales por el oro empleado, 3,300 reales por el estofado de las imágenes y 5,995 reales por el pago de los jornales, materiales y andamiajes. A todo ello se le sumaban 500 reales de las lámparas. En el policromado y dorado del retablo trabajó José de Bustos, ascendiendo el costo del dorado del manifestador a siete libros de oro y el montaje de los andamiajes se encargó Pedro Jiménez. ${ }^{77}$

La documentación del conjunto escultórico como obra del imaginero Domingo Cabrera se constata mediante la información aportada por las actas capitulares y por una serie de libranzas que a continuación describimos. No obstante, no descartamos que trabajase junto a Blas Moreno, quien se ocuparía de la talla del retablo. ${ }^{78}$ De este modo nuestro imaginero emularía, entre otros, a Agustín Vera Moreno, que trabajó con él en el retablo mayor de la parroquia granadina de San Miguel..$^{79}$ Sabemos que el maestro de escultura afron-

76. Trabajó como ensamblador en San Ildefonso, concretamente en el retablo mayor, obra de I730 de Blas Antonio Moreno, siendo sus esculturas de José Risueño, y en el retablo de ánimas, sucediéndose sus trabajos asimismo en las puertas de los antecamarines de la Basílica de Nuestra Señora de las Angustias. Juan Jesús López y Guadalupe Muñoz, "Del Barroco avanzado al neoclasicismo en la retablística granadina del setecientos", Cuadernos de Arte de la Universidad de Granada, núm. 29 (1998): 94-95.

77. Contamos con un recibo del 24 de diciembre de 1746 firmado por Pedro Ximenes, que también trabajó en el montaje del andamio para blanqueo y colocación de la imagen de San José de uno de los retablos colaterales de la Basílica de Nuestra Señora de las Angustias. Palomino Ruiz, "Patrocinio y mecenazgo de Gregorio Eugenio de Espínola", 7I-80.

78. Esta teoría fue defendida por Antonio Gallego y Burín, quien dijo de este artífice que "representa una síntesis de los influjos de Hurtado y de Bada" y lo dató entre 1745-1747. La misma idea fue seguida, entre otros, en López y Muñoz, "Del Barroco avanzado al neoclasicismo en la retablística granadina del setecientos", 94. En otros casos se había hablado, sin embargo, de Pedro Duque Cornejo, siguiendo lo expresado en Manuel Gómez-Moreno, Guia de Granada, ed. José Manuel Gómez-Moreno Calera (Granada: Universidad de Granada, I998), 472.

79. Juan Jesús López-Guadalupe Muñoz, "El mecenazgo artístico en la Granada del siglo xvıII. La financiación del arte religioso", Revista del Centro de Estudios Históricos de Granada y su Reino, núms. IO-II (I996-1997): 336-337. 
tó también el dorado (estofado) y policromado de ellas por un memorial del propio artista relatado en el cabildo del 30 de julio de 1748 . Este dato aumenta el interés por el referido escultor dado que lo sitúa además de como tallista, como policromador y estofador, confirmándonos su procedencia granadina. En la primera parte del mismo aparece como: "vezino desta ciudad y maestro de escultura de ella", afirmando asimismo haber "corrido a cargo del suplicante el dorado y pintura de los santos situados en el retablo del altar mayor de la iglesia collegial de vuestra señoría ilustrísma, vajo el ajuste de trescientos ducados" ${ }^{80}$ Sin embargo, esta obra se vio pronto envuelta en una serie de vicisitudes, como el retraso en los pagos de 2,I00 (y más) reales, por lo que manifestó su urgencia, debido a que necesitaba dicha cantidad para satisfacer a los trabajadores que se encontraban a su cargo. Por ello hizo saber al cabildo del Sacro Monte, en la persona de su abad, Gaspar Salcedo, la acuciante necesidad de que se le efectuase el pago de los reales que se le debían, proponiéndose que si continuaba el retraso, se le debería ingresar una ración diaria en el tiempo en el que se realizaba dicho cargo. Estas prisas del escultor las entendemos como fruto de la necesidad de satisfacer a los miembros de su taller que, a buen seguro, le acompañaron en esta empresa. Una vez reflejado el memorial, el cabildo concluyó instando a que Laboraria, como comisario, informase a Cabrera del pronto pago de alguna cantidad para socorrer sus gastos y que ambos acordarían unos plazos, con dinero procedente de las rentas de fábrica. ${ }^{8 \mathrm{r}}$ Como resultado del compromiso acordado en el acta capitular, contamos con una libranza del I2 de agosto de I748. En ella se libraron 400 reales de los 300 ducados del costo total, entregados por el mayordomo de la mesa capitular y fábrica del Sacro Monte, Damián Navarro. La libranza confirma al maestro escultor Domingo Cabrera, como autor de las esculturas del retablo mayor, contando en el reverso con su firma y rúbrica.

[al margen]: Puédense librar. Son 400 reales de vellón a don Domingo Cabrera, en quenta y parte de pago de mayor cantidad, que se le está debiendo de la hechura de los santos del retablo de la iglesia deste Sacromonte.

Señor don Damián Navarro, mayordomo de la Mesa Capitular y fábrica de este Sacromonte, por la presente entregará vuestra merced, quatrocientos reales de vellón a don Domigo Cabrera, maestro de escultor, para en quenta y parte de pago de mayor

80. Creemos que esta cantidad incluía también la talla.

8I. AAsGr, Fondo Abadía, Actas de cabildo, lib. 9, leg. 26I, 30 de julio de I748, fols. 30v-3Ir. 
cantidad que se le está debiendo de los trescientos ducados en que ajustó, y hizo los santos del retablo del altar mayor de nuestra iglesia, que con esta libranza y recivo del susodicho se abonará a vuestra merced en quenta de la cantidad de su obligazión, destinada para obras y pleitos, aviéndose tomado la razón en nuestra contaduría.

Sacromonte y agosto doze de mill setecientos quarenta y ocho años.

Doctor Salzedo [firmado y rubricado].

Doctor Vázquez [firmado y rubricado]. ${ }^{82}$

La evolución del proceso tomó un tiempo, como procede en una obra de tan elevada magnitud. A propósito de ello, gracias a las libranzas despachadas en la contaduría del Sacro Monte durante los años 1747 y 1748 manejamos información de gran utilidad. Por ellas, por ejemplo, nos consta que, como expresaba con anterioridad, ante la demora de los caudales de Gregorio de Espínola, el cabildo del Sacro Monte se ocupó de los trámites dedicados a costear el retablo, mediante su hacienda y fábrica. Con base en esto, en una libranza del II de febrero de I747, se relata el pago de 58 reales a Miguel de Reina, para el aumento de su decoro.

[al margen]: Son 58 reales vellón al señor Reina, thesorero, para pagar los calnados de las rejas del altar mayor y los cordones del manifiesto del retablo nueuo.

Puedense librar el señor doctor Damián Nauarro, maiordomo de las haziendas de messa y fábrica deeste Sacromonte, por la presente entregará vuestra merced cinquenta y ocho reales vellón al señor don Miguel de Reina, canónigo thesorero de nuestra yglesia, para que dicho señor pague los quarenta, digo los treinta reales que han costado los calnados de las rejas del retablo nuebo y los veinte y ocho reales restantes que han costado los cordones de seda del manifiesto de dicho retablo, que con esta libranza y reziuo de dicho seńor se auonaran a vuestra merced, en quenta de la cantidad destinada para obras, etc. Auiéndose tomado la razón en nuestra contaduría.

Sacromonte y febrero, onze de mill setezientos quarenta y siete años.

Doctor Salcedo [firmado y rubricado].

Doctor Laboraria [firmado y rubricado]. ${ }^{83}$

La prolongación de la empresa, así como la demora en la llegada de los fondos de Espínola, provocó que esta ayuda tuviera que verse respaldada por la

82. AASGr, Fondo Abadía, Libranzas despachadas para obras y pleitos y otros gastos en los años de I747 y 1748 que valen $I I .749$ reales y 2 maravedis, leg. 8 .

83. AASGr, Fondo Abadía, Libranzas despachadas para obras y pleitos y otros gastos en los años de I747 y 1748 que valen 11.749 reales y 2 maravedis, leg. 8 . 
memoria de Aponte, procedente de la localidad gaditana del Puerto de Santa María, empleada para el pago del dorado. Se hacen eco de ello las cuentas del Sacro Monte de los años I747-I795. ${ }^{84}$ En primer lugar, en cabildo del ro de octubre de 1746 , se dio lectura a una carta del comisario de caridad del Puerto de Santamaría, Pedro Francisco Voz, dirigida al canónigo Martín Vázquez de Figueroa, en la que le indicaba su deseo de cumplir con su compromiso con el cabildo y satisfacer la parte que a éste le correspondía de la partición de las memorias de Aponte (la parte cuarta):

Item, leí vna carta de Pedro Francisco Voz, comisario de la charidad en el Puerto de Santa María, dirigida a el señor Básquez, en la qual respondía estaba prompto a executar lo que dicho seńor Básquez le avia escrito, de orden de este cavildo, en razón de la partición de la cantidad que estaba en ser, y pertenecía a este cavildo por la quarta parte de las memorias del seńor Aponte, y con las referidas determinaciones se disoluio este cavildo de que doi fee. ${ }^{85}$

Sin embargo hay que esperar al cabildo de 2 I de febrero de I747, para que se negocien las disposiciones que se habían de tomar con el dinero recibido. ${ }^{86}$ En efecto, en la partida número i de la entrada de capitales del señor Aponte de 1747 , se nos habla de I0,062 reales y 20 maravedís que entraron en el nego-

84. AASGr, Fondo Abadía, Estado de los capitales de la Mesa Capitular, fábrica, capellanía, memoria y patronatos de este Sacro Monte, desde principios de 1746 hasta fin de 1795, leg. 70. También nos constan los recibos de pagos efectuados por Gregorio Eugenio de Espínola en I3 de diciembre de 1745 y 5 de julio de 1746 , entre otros, sin fechar. En el relicario, Domingo Cabrera se encargó del trabajo de la talla, recibiendo por ello 230 reales. Si bien, en este caso podemos decir que la factura está revestida de un mayor clasicismo que en el retablo mayor. Su pericia en la resolución de tipos arquitectónicos se demuestra tanto en su astil, a modo de cuerpos geométricos superpuestos, de formas troncocónicas, como en la urna. De tipo templete, está sustentada por atlantes infantiles y se encuentra rematada por una cúpula sobre la que se alza triunfante la figura de la fe. A su vez está compuesta por columnas con capiteles de hojas de acanto, sobre las que descansan entablamentos arquitectónicos, los cuales sirven de peana para angelillos portadores de cartelas. Palomino Ruiz, "Patrocinio y mecenazgo de Gregorio Eugenio de Espínola", 7I-77.

85. AAsGr, Fondo Abadía, Actas de cabildo, lib. 8, leg. 26I, io de octubre de I746, f. 48Iv.

86. Recordemos que la primera vez que tenemos constancia de la ayuda de la memoria de Aponte es en la libranza del 28 de febrero de 1747. AASGr, Fondo Abadía, "Estado de los capitales de la Mesa Capitular, fábrica, capellanía, memoria y patronatos de este Sacro Monte, desde principios de 1746 hasta fin de 1795 ", leg. 70 y AAsGr, Fondo Abadía, Actas de cabildo, lib. 8, leg. 26I, 2I de febrero de i747, fols. 502r-v. 
cio de la memoria de Aponte y que por decreto de cabildo ${ }^{87}$ se remitieron en préstamo a la memoria de Espínola para el pago del retablo del altar mayor:

Primeramente, en 28 de febrero de 1747 se entraron en arcas de capitales del seńor Aponte, diez mil sesenta y dos rreales y veinte maravedís de vellón, que remitió en letra don Francisco de Boz, Ajente del cavildo en el Puerto de Santa María, en el negocio de la memoria del Señor Aponte, y esta cantidad, por decreto del cavildo de 3 de dicho mes se prestó a las memorias de Spínola, para el retablo de el altar maior de este Sacro Monte y al folio 213 del libro de arcas constan la salida por tres libranzas y el reintegro que hizo Spínola, consta tamvién a los folios 33 buelto, en 2 I de marzo de $1750 \ldots 2.000$

Folio 219, asiento I4 de julio de 1749 ... I.639

Folio 220 buelto, en 4 de julio de 1750 ... 6.423-I4

Y añadiéndose los 6 maravedís que en la cuenta de Spínola se ponen por pagados a esta memoria, resulta íntegramente estar satisfecha...06

Supuestas estas entradas y salidas, para que nada se ignore de lo ocurrido sobre esta partida: resultan verdaderamente puestos en arcas de capitales del seńor Aponte y por primera partida de ellos: diez mill sesenta y dos reales y veinte maravedís... 10.062-20. ${ }^{88}$

En concomitancia con ello, en el cabildo del 3 de marzo de 1747 se acordó emplear los ı,, 000 reales pertenecientes a la memoria del señor Aponte para sufragar el dorado del retablo, hasta que arribase el dinero de Espínola. ${ }^{89}$ Como vemos, esta sesión capitular fue probatoria de la confianza depositada por el Sacro Monte en la figura de Gregorio de Espínola y la necesidad que había de continuar con la obra. Por ello, en el acta se manifestó el deseo del abad, Gaspar Salcedo, de continuar con el dorado del retablo, debido a que ya se había puesto en pie toda la infraestructura necesaria y no era menester demorarse en el tiempo. Ante esta situación, el beneficiado de las Angustias se comprometió a dar I0,000 reales entre abril y mayo, y los Io,০oo restantes antes del día de san Juan, con la esperanza de poder vender algunos frutos con anterioridad a esta fecha. Esta idea fue expuesta por la junta de administración, quien pro-

87. Buscado en las actas capitulares no he localizado el referido cabildo del 3 de febrero de 1747. 88. AASGr, Fondo Abadía, Estado de los capitales de la Mesa Capitular, fábrica, capellanía, memoria y patronatos de este Sacro Monte, desde principios de 1746 hasta fin de 1795, leg. 70.

89. Gaspar Salcedo alegó como motivo principal el haberse puesto en pie todo el andamiaje necesario. 
puso al cabildo utilizar los I.00o reales procedentes de la memoria de Aponte los cuales habían mandado poner en arcas, a causa de no tener en el momento propiedades "seguras en que imponerlos". El cabildo la aprobó, teniendo presente que Gregorio de Espínola se trataba de un "hombre mui formal y que no faltaría a lo prometido", y confió en que dicha cantidad se reemplazaría a la comisión cuando pagase la parte que faltaba..$^{90} \mathrm{El}$ archivo de la abadía del Sacro Monte dejó constancia de tres libranzas del año de 1747 dadas a Laboraria. Dicho dinero se trata de los $\mathrm{I}, 062$ reales y 20 maravedís entregados por Pedro Francisco de Voz, secretario de la Hermandad de la Caridad del Puerto de Santa María, a la memoria de Francisco de Aponte, en respuesta a lo establecido en cabildo antes citado, del 3 de marzo. ${ }^{\text {I }}$

Correspondiendo con estas libranzas, en cabildo de I5 de mayo de 1747, el abad, Gaspar Salcedo, constató haber sido consultado por el presidente de la Chancillería, Juan Francisco de Isla y Vallado, acerca del estado del dorado del retablo mayor de la iglesia..$^{92}$

No obstante, un año después aún no había finalizado de pagarse el dorado del retablo. Así lo vemos en el cabildo del 20 de febrero de 1748, el cual representa una secuencia de medidas tomadas para este fin. En primer lugar, se manifiesta el deseo de llevar a cabo la liquidación de las rentas de los capitales de la memoria de Aponte. Ante esto, el cabildo incitó al canónigo Vázquez para que cobrase dicho dinero y lo dispusiese en arcas de capitales, demostrando el interés de Gregorio de Espínola, que "avía explicado su voluntad de dorarlo también a su costa”. Para ello Espínola se comprometió a integrar los 20,000 reales del coste del dorado en el espacio temporal de dos meses. No obstante, el cabildo motivado por la necesidad de comprimir al máximo el tiempo de obra del retablo, con el fin de que pronto ocuparan el lugar que les corresponde las respectivas reliquias y se pudiera celebrar en él de modo ordinario sin el estorbo de los andamios, acordó que el canónigo Vázquez pagase io,ooo reales a los comisarios del dorado, en préstamo, a la espera de que fuesen entregados por el devoto. Esto se debe a que Gregorio de Espínola solamente había contribuido con 3,500 reales, los cuales constituían una parte de los utilizados en "las andamiadas, aparejos para el dorado y dorado del manifestador y de las

90. AASGr, Fondo Abadía, Actas de cabildo, lib. 8, leg. 261, 3 de marzo de 1747, fols. 504r-v.

9I. AASGr, Fondo Abadía, Libranzas de 1747, leg. I53.

92. Pedro Gan Giménez define su mandato como breve y poco interesante. Pedro Gan Giménez, "Los presidentes de la Chancillería de Granada en el siglo XvIII", 248 y AASGr, Fondo Abadía, Actas de cabildo, lib. 8, leg. 26I, I5 de mayo de 1747, fols. 527v-528r. 
quatro vrnas y el Sagrario de dicho retablo". Con este motivo se le había solicitado que vendiese bienes de su hacienda (animando a ello también a Gaspar Salcedo). Sin embargo, debido a que la liquidación de la memoria de Aponte se encontraba detenida por un reparo expuesto por Luis de Viana sobre la necesidad de tener conocimiento de los gastos a causa de los pleitos con el Consejo de Guerra, ${ }^{93}$ se propuso que el señor Viana estudiara el modo de llevarla a cabo, aceptándose cumplir con su propuesta consistente en sumar los gastos. ${ }^{94}$ Sin embargo, posteriormente, en cabildo del 4 de abril de 1748 , se otorgó la confirmación del empleo en el pago del dorado del retablo mayor de los Io,00o reales procedentes de la memoria de Aponte, tal y como se había acordado por junta de administración. No obstante, según informa Gaspar Salcedo, esto se hizo a sabiendas del ofrecimiento de Gregorio de Espínola de reintegrarlos con premura. Ante ello se planteó la necesidad de citar a cabildo, para cotejar la conveniencia de reconocer un censo en favor de la memoria de Aponte de la hacienda utilizada en el retablo de los Iо,000 reales, hasta que Espínola hiciese el ingreso. ${ }^{95}$

Gracias al libro de mayordomía de los siglos XVII y XVIII, tenemos constancia de que los pagos del dorado del retablo mayor se sucedieron hasta la fecha de 1749. En él encontramos una serie de libranzas, despachadas a José de Bustos, administrador del patronato de Miguel Muñoz de Ahumada, ligadas a la capellanía de Gregorio de Espínola. Llama la atención la partida número 27 , relativa a la libranza del 3 de mayo de 1748 , vinculada al pago del dorado. ${ }^{96} \mathrm{En}$ esta misma línea la partida número 29 data del año previo al fallecimiento de Gregorio de Espínola, el I7 de junio de 1749. Asciende a 469 reales, que debía Espínola al administrador por el dorado del retablo del altar y procedían de Ioo ducados de las rentas de su capellanía. A continuación, en la partida número 30, datada en el mismo día, 17 de junio, se deja constancia de la libranza de 63I reales a Gregorio de Espínola para acabar de pagarla hasta finales de octubre de 1748. Ella se libra en nombre de Espínola al abad, Gaspar Salcedo, para costear parte de lo que el beneficiado debía del dorado del retablo. Por otro lado, en la partida 33 se halla la libranza del i7 de febrero de I750, consistente en I,IOo reales a Gregorio de Espínola, para costearle su capellanía de un año,

93. Al agente del Consejo de Guerra, presente en Madrid, se le había asignado, a modo de salario, la beca de un hijo suyo, colegial en el Sacro Monte (siendo entera los tres primeros ańos). 94. AASGr, Fondo Abadía, Actas de cabildo, lib. 9, leg. 26I, 20 de febrero de 1748, fols. 2v-3v. 95. AASGr, Fondo Abadía, Actas de cabildo, lib. 9, leg. 26I, 4 de abril de 1748, fols. I7r-v. 96. AASGr, Fondo Abadía, Libro de mayordomía de la hacienda de Granada desde 1695, leg. 205, f. I6r. 
hasta octubre de I749, y de nuevo se le libra, en su nombre, a Gaspar Salcedo parte del pago que Espínola debía del coste del retablo. Por último, la partida número 34 se refiere al pago de 336 reales y 8 maravedís, por libranza del 30 de marzo de 1750 , a los albaceas del maestro Espínola de la renta de la capellanía de Ahumada que dicho beneficiado heredó, con el título de San Miguel. La misma tenía de duración tres meses y veinte días, concretamente hasta el fallecimiento de Espínola, el 20 de febrero del citado año de 1750. Presentaba por cargo 3I misas, las cuales debería haber dicho por su capellanía, el difunto. Con esto se demuestra que, a pesar de la buena voluntad de Gregorio de Espínola, no cumplió con todas sus promesas al Sacro Monte en vida. Empero, sabemos que ordenó por medio de su testamento que se abonasen todas sus deudas concernientes al dorado del retablo:

Que del producto de sus vienes se sacaren seismill quattrocienttos veintte y tres rreales y cattorce marauedís, que esttaua rresttando del dorado del rrettablo del alttar maior de la citada insigne yglesia collexial, que de su orden se auía he-/[2ov]cho y concluido, supliendo para ello a pedimentto suio el capittal de la memoria de el excelentísimo señor Aponte, que esttaua en arcas, la rreferida canttidad con la qual se concluió el dorado del dicho rretablo, por lo que como dicho es, fue su bolunttad se rreinttegrase dicha memoria de el suplimientto que auía hecho, por lo que en obserbancia y cumplimientto de el dicho comunicatto, por lo seńores abad y cabildo, como ttal eredero, se despachó libranza de los dichos seismill quattrocienttos veintte y ttres rreales y cattorce marauedís, conttra el nominado señor canónigo deposittario, quien los//[3or] sattisfizo y enttregó en las arcas de capittales, firmando su rreciuo los señores canónigos claueros deellas, quedando rreemplazada la memoria del dicho excelentísimo seńor Aponte y cumplica en quantto a este particular la bolunttad del dicho testador. ${ }^{97}$

Esto demuestra un enorme interés de parte del mecenas en satisfacer sus deudas con la institución y en definitiva revela su involucramiento decidido en la fábrica del retablo, algo que fue tanto con carácter inter vivos, como post mortem. Junto con la satisfacción de las deudas del retablo, Gregorio de Espínola dejó en el Sacro Monte un importante legado por medio de la fundación de un patronato.

97. AASGr, Fondo Abadía, Testamentos de Espinola, leg. 50. 
DOI: https://doi.org/10.22201/iie.18703062e.2020.116.2716

I28

JOSÉ MARÍA VALVERDE TERCEDOR

\section{Conclusiones}

Considero que la documentación inédita aportada en esta investigación nos ayuda a conocer los ricos y simbólicos ceremoniales barrocos que precedieron a cada uno de los actos religiosos que estuvieron ligados al cambio del retablo del Sacro Monte. En este contexto, reviste una gran elocuencia, la apertura de la fábrica antigua y el correspondiente movimiento de reliquias, protagonizado tanto por el presidente de la Chancillería como por los miembros más destacados de la iglesia granadina y los monarcas Felipe V y Fenando VI. Por otro lado, creo de relevancia dar a conocer al escultor granadino Domingo Cabrera, hasta el momento prácticamente ignorado, y al que esta obra lo sitúa, sin lugar a dudas, en un puesto destacado entre la imaginería de la ciudad de la Alhambra de la centuria dieciochesca. Por último, se antoja necesario ponderar las distintas personas que se ocuparon de idear, gestionar y sufragar el proyecto del nuevo retablo mayor, entre los que brillan con luz propia el mecenas, Gregorio Eugenio de Espínola, y los canónigos, José de Laboraria y Luis de Viana, quienes, sin lugar a dudas, encontraron en este retablo un apoyo inmenso a los defensorios que en este momento se estaban desarrollando en la abadía y que sirvieron como caldo de cultivo a los descubrimientos de la Alcazaba Qadima del Albaicín. \$ 